\title{
Muscarinic Receptor Activation Modulates Granule Cell Excitability and Potentiates Inhibition onto Mitral Cells in the Rat Olfactory Bulb
}

\author{
R. Todd Pressler, Tsuyoshi Inoue, and Ben W. Strowbridge \\ Department of Neurosciences, Case Western Reserve University, Cleveland, Ohio 44106
}

\begin{abstract}
The olfactory bulb is a second-order brain region that connects sensory neurons with cortical areas. However, the olfactory bulb does not appear to play a simple relay role and is subject instead to extensive local and extrinsic synaptic influences. Prime among the external, or centrifugal, inputs is the dense cholinergic innervation from the basal forebrain, which terminates in both the granule cell and plexiform layers. Cholinergic inputs to the bulb have been implicated in olfactory working memory tasks in rodents and may be related to olfactory deficits reported in people with neurodegenerative disorders that involve basal forebrain neurons. In this study, we use whole-cell recordings from acute rat slices to demonstrate that one function of this input is to potentiate the excitability of GABAergic granule cells and thereby modulate inhibitory drive onto mitral cells. This increase in granule cell excitability is mediated by a concomitant decrease in the normal afterhyperpolarization response and augmentation of an afterdepolarization, both triggered by pirenzepine-sensitive $M_{1}$ receptors. The afterdepolarization was dependent on elevations in intracellular calcium and appeared to be mediated by a calciumactivated nonselective cation current $\left(I_{\mathrm{CAN}}\right)$. Near firing threshold, depolarizing inputs could evoke quasipersistent firing characterized by irregular discharges that lasted, on average, for $2 \mathrm{~min}$. In addition to regulating the excitability of the primary interneuronal subtype in the bulb, $M_{1}$ receptors regulate the degree of adaptation that occurs during repetitive sniffing-like inputs and may therefore play a critical role in regulating short-term plasticity in the olfactory system.
\end{abstract}

Key words: olfactory bulb; GABA; granule cell; interneuron; ACh; synapse; modulation

\section{Introduction}

The olfactory bulb plays a critical role in relaying sensory information from receptor neurons located in the nasal epithelium to olfactory cortical structures (Shepherd and Greer, 1998). However, mitral cells, the principal neurons in the olfactory bulb, do not function as simple cellular relays. Instead, mitral cell behavior is governed by a constellation of complex intrinsic conductances (Chen and Shepherd, 1997; Balu et al., 2004; Balu and Strowbridge, 2007) and synaptic interactions including the dendrodendritic reciprocal synapses (Rall et al., 1966; Jahr and Nicoll, 1980; Isaacson and Strowbridge, 1998) commonly associated with the olfactory bulb. Also contradicting a simple relay function are the dense centrifugal projections into the bulb, including the large cholingeric input from projection neurons in the nucleus of the horizontal limb of the diagonal band of Broca (HDB) (Macrides et al., 1981; Luskin and Price, 1982; Zaborszky et al., 1986). Experimental interventions that disrupt cholinergic receptor-

Received March 1, 2007; revised Aug. 14, 2007; accepted Aug. 20, 2007.

This work was supported by National Institutes of Health Grant DC04285 (B.W.S.). T.I. was supported by a Fellowship from the Sankyo Foundation. We thank Ram Balu, Phil Larimer, and Christiane Linster for helpful discussions and constructive comments on this manuscript.

Correspondence should be addressed to Dr. Ben W. Strowbridge, Department of Neurosciences, Case Western Reserve University, 10900 Euclid Avenue, Cleveland, OH 44106. E-mail: bens@case.edu.

T. Inoue's present address: Department of Information Physiology, National Institute for Physiological Sciences, Okazaki 444-8787, Japan.

D0I:10.1523/JNEUROSCI.2961-07.2007

Copyright $\odot 2007$ Society for Neuroscience $\quad 0270-6474 / 07 / 2710969-13 \$ 15.00 / 0$ mediated signaling in the olfactory bulb often have profound effects on olfactory-related behaviors in rodents (Ravel et al., 1992, 1994; Roman et al., 1993; Linster et al., 2001a; Fletcher and Wilson, 2002; Linster and Cleland, 2002) whereas treatments that augment cholinergic function can enhance performance on olfactory discrimination tasks (Doty et al., 1999). In humans, olfactory dysfunction is often associated with neurodegenerative disorders, including Alzheimer's disease, that involve basal forebrain cholinergic neurons (Ferreyra-Moyano and Barragan, 1989; Durand et al., 1998; Albers et al., 2006). Understanding how centrifugal inputs regulate neuronal network activity in the olfactory bulb is a critical step necessary to decipher the normal function of this brain region and its potential involvement in neurological diseases.

Although the olfactory bulb expresses an abundance of muscarinic and nicotinic cholinergic receptor subtypes (Le Jeune et al., 1995, 1996), relatively little is known about the cellular mechanisms responsible for cholinergic signaling in the bulb. Only two studies (Castillo et al., 1999; Ghatpande et al., 2006) used intracellular recordings in rodent brain slices to investigate the physiological consequences of cholinergic receptor-mediating signaling in the olfactory bulb. Both studies found evidence for presynaptic muscarinic receptors that regulate transmitter release. Castillo et al. (1999) also used cell-attached recordings to test for potential postsynaptic responses on interneurons. They found that relatively high concentrations of the cholinergic re- 
ceptor agonist carbachol (CCh; 50-100 $\mu \mathrm{M}$ ) depressed the spontaneous firing rate of GABAergic granule cells, leading this group of researchers to postulate that postsynaptic muscarinic receptors depress granule cell excitability. Paradoxically, the same study found that $\mathrm{CCh}$ strongly facilitated spontaneous spikedependent IPSCs recorded in mitral cells, the postsynaptic targets of inhibitory granule cells. The explanation for the contradiction between the apparent inhibitory postsynaptic effect on granule cells and the facilitatory effect on spike-dependent transmitter release after muscarinic receptor stimulation remains unresolved. No previous studies have used intracellular recordings to define the cellular mechanisms responsible for postsynaptic muscarinic receptor-mediated signaling in the olfactory bulb.

In this study, we used whole-cell intracellular recording and Ca uncaging methods to define the muscarinic responses in granule cells and the primary functional consequence of this modulation in the olfactory bulb circuit (see Fig. $1 A$ ). We found that relatively low concentrations of CCh $(2 \mu \mathrm{M})$ activate $\mathrm{M}_{1}$ receptors on granule cells and produce two principal effects: abolition of the normal afterhyperpolarization (AHP) that follows clusters of action potentials and recruitment of a latent afterdepolarization (ADP) response. The ADP response we found in granule cells exposed to $M_{1}$-specific receptor agonists or low concentrations of CCh was graded in amplitude and could be amplified either by triggering more action potentials or by elevating receptor agonist concentrations. When granule cells are excited using slow, phasic stimuli that mimic the synaptic drive bulbar neurons receive during sniffing, activation of muscarinic receptors potentiates both granule cell discharges and mitral cell inhibition. Our results suggest that one function of cholinergic inputs to the olfactory bulb may be to regulate the granule cell excitability and the rate at which granule cell responses adapt during sniffing.

\section{Materials and Methods}

Horizontal slices (300 $\mu \mathrm{m}$ thick) from the olfactory bulbs of 14- to 25d-old Sprague Dawley rats were prepared as described previously (Isaacson and Strowbridge, 1998; Halabisky et al., 2000; Pressler and Strowbridge, 2006) and placed in a submerged recording chamber on the stage of an upright microscope (Axioskop FS; Zeiss, Thornwood, NY). Slices were continuously perfused at $30^{\circ} \mathrm{C}$ with standard artificial CSF (ACSF) that contained (in mM) $124 \mathrm{NaCl}, 3 \mathrm{KCl}, 1.23 \mathrm{NaH}_{2} \mathrm{PO}_{4}, 1.2 \mathrm{MgSO}_{4}, 26$ $\mathrm{NaHCO}_{3}, 10$ dextrose, and $2.5 \mathrm{CaCl}_{2}$ that was equilibrated with $95 \%$ $\mathrm{O}_{2} / 5 \% \mathrm{CO}_{2}$. In the experiment shown in Figure 2C, the driving force for $\mathrm{Na}$ ions was reduced by partially replacing $\mathrm{Na}$ ions $(99 \mathrm{mM})$ with isotonic $\mathrm{N}$-methylglucamine (NMG), as described previously (Pressler and Strowbridge, 2006). We adjusted the $\mathrm{pH}$ of NMG ACSF solutions to 7.4 by adding $\mathrm{HCl}$. Whole-cell current-clamp and cell-attached recordings were made using a $\mathrm{K}$-methylsulfate based internal solution that contained (in mM) $140 \mathrm{~K}$-methylsulfate, $4 \mathrm{NaCl}, 10 \mathrm{HEPES}, 0.2$ EGTA, 4 MgATP, $0.3 \mathrm{Na}_{3} \mathrm{GTP}$, and 10 phosphocreatine. The same internal solution with the addition of $10 \mathrm{~mm}$ BAPTA and $1.3 \mathrm{~mm} \mathrm{CaCl}_{2}$ was used for the Ca chelating experiment shown in Figure $1 B$. The estimated intracellular $\mathrm{Ca}$ concentration with this BAPTA-containing internal solution was $53 \mathrm{~nm}$ (Patton et al., 2004). Most voltage-clamp recordings used an internal solution containing (in mM) 115 Cs-methanesulfonate, 25 tetraethylammonium (TEA)-methanesulfonate, 10 HEPES, 5 QX-314 $(\mathrm{N}$ ethyl bromide), $4 \mathrm{NaCl}, 4 \mathrm{MgATP}, 1$ EGTA, $0.3 \mathrm{Na}_{3} \mathrm{GTP}$, and 10 phosphocreatine. The voltage-clamp recordings shown in Figure 6, $A_{2}$ and $E$, used a CsCl-based internal solution that contained (in $\mathrm{mM}$ ) $115 \mathrm{CsCl}, 4$ $\mathrm{NaCl}, 10$ HEPES, 0.2 EGTA, $4 \mathrm{MgATP}, 0.3 \mathrm{Na}_{3} \mathrm{GTP}$, and 10 phosphocreatine. All drugs except for TTX (EMD Biosciences, San Diego, CA) and $o$-nitrophenyl EGTA (NP-EGTA; Invitrogen, Eugene, OR) were obtained from Sigma (St. Louis, MO).

In the Ca uncaging experiments shown in Figure 2, $E$ and $F$, we used an internal solution that contained (in mM) 118 Cs-methanesulfonate, 25 TEA-methanesulfonate, $10 \mathrm{HEPES}, 4 \mathrm{NaCl}, 4 \mathrm{MgATP}, 1$ EGTA, 0.3
Na3GTP, 10 phosphocreatine, and 2 NP-EGTA, and an extracellular solution that contained TTX $(1 \mu \mathrm{M})$. Control responses were obtained using the same internal solution with no added NP-EGTA. We used a 150 W Xe short-arc lamp (Opti-Quip, Highland Mills, NY) controlled by a fast electronic shutter (Uniblitz; Vincent Associates, Rochester, NY) to photolyze NP-EGTA (Ellis-Davies and Kaplan, 1994; Pressler and Strowbridge, 2006), which was loaded by one depolarizing step to $0 \mathrm{mV}$ (250 $\mathrm{ms}$ duration) immediately before the exposure. The output of the Xe lamp was directed toward the microscope objective (Zeiss $63 \times$ waterimmersion; numerical aperture, 0.9) using a long-pass dichroic mirror designed for the epifluorescent detection of fura-2 (400DCLP; Omega Optical, Brattleboro, VT).

Individual granule, Blanes, and mitral cells were visualized using infrared-differential interference contrast optics and a CCD camera (Cohu, Poway, CA). Blanes cells could be readily differentiated from the more numerous granule cells located in the same layer because of their larger cell body and distinctive electrophysiology (Pressler and Strowbridge, 2006). Granule cells filled with $100 \mu \mathrm{M}$ Alexa594 through the patch pipette were visualized in the experiment shown in Figure $4 E_{3}$ using two-photon microscopy, as described previously (Pressler and Strowbridge, 2006). Whole-cell and cell-attached recordings were made using an Axopatch 1D amplifier (Molecular Devices, Sunnyvale, CA). Series resistance was typically $<15 \mathrm{M} \Omega$ and was routinely compensated by $>80 \%$ in voltage-clamp experiments (electrode resistance typically 2-4 M $\Omega$ ). Voltage and current records were low-pass filtered at $2 \mathrm{kHz}$ and sampled at $5 \mathrm{kHz}$ using an ITC-18 16-bit analog-to-digital converter (Instrutech, Port Washington, NY) using custom software written in Visual Basic 6 (Microsoft, Redmond, WA). Custom Visual Basic routines and Origin 7.5 (OriginLab, Northhampton, MA) were used to analyze intrinsic and synaptic responses. Input resistance was assayed by measuring responses to small hyperpolarizing current steps applied near rest. Synaptic responses were evoked using tungsten monopolar electrodes (FHC, Bowdoin, ME) connected to a constant-current stimulus isolation unit (model A360; World Precision Instruments, Sarosota, FL). The experiments presented in Figures 5, $A$ and $B$, and $6 D$ used slow phasic current injection waveforms, based on summated $\alpha$ functions, whose properties have been described previously (Halabisky and Strowbridge, 2003; Balu et al., 2004). Pharmacological agents were applied by switching the perfusion solution. Voltages presented are not corrected for the liquid junction potential. Except where noted, statistical significance was determined using Student's $t$ test. Data are presented as mean \pm SEM. Spike jitter was assessed by calculating the SD of the action potential latency. Except where noted, the magnitude of afterpotentials in granule and Blanes cells were quantified by calculating either the amplitude of the peak response (average of three data points; peak time floating) or the integral of the membrane potential over $2 \mathrm{~s}$. Spike frequency adaptation ratios were calculated by comparing the mean firing frequency (Freq) in two successive $150 \mathrm{~ms}$ windows (Freq $\mathrm{Late} /$ Freq $_{\text {Early }}$ ).

\section{Results}

\section{Cholinergic modulation of afterpotentials in granule cells}

Bursts of action potentials trigger long-duration AHPs in olfactory bulb granule cells (Fig. $1 B$ ) (mean AHP amplitude, $-3.7 \pm$ $0.9 \mathrm{mV} ; n=10$ cells). We recorded AHPs after both weak (50-70 $\mathrm{pA}$, generating $1-5$ spikes in $500 \mathrm{~ms}$ ) and strong (generating $>5$ spikes) depolarizing steps in control granule cells. Bath application of the cholinergic receptor agonist CCh $(2 \mu \mathrm{M})$ reliably converted this AHP response into an ADP (mean amplitude when elicited at $-60 \mathrm{mV}, 3.0 \pm 0.8 \mathrm{mV} ; n=10$; AHP to ADP conversion in 81 of 96 granule cells tested systematically with $2 \mu \mathrm{M} \mathrm{CCh}$; $p<0.0001, \chi^{2}$ test). The ADP response in granule cells appeared to be triggered by elevations in intracellular $\mathrm{Ca}$ because $\mathrm{CCh}$ failed to convert AHP responses in cells recorded with internal solutions containing high concentrations of the Ca chelator BAPTA ( $10 \mathrm{~mm}$; zero of three cells tested) (Fig. $\left.1 B_{1}\right)$.

Cholinergic receptor agonists did not modulate afterpotentials in all cell types in the granule cell layer. Blanes cells, another 


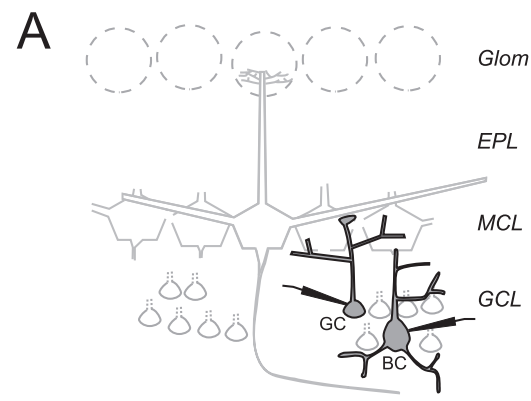

$\mathrm{B}_{1}$

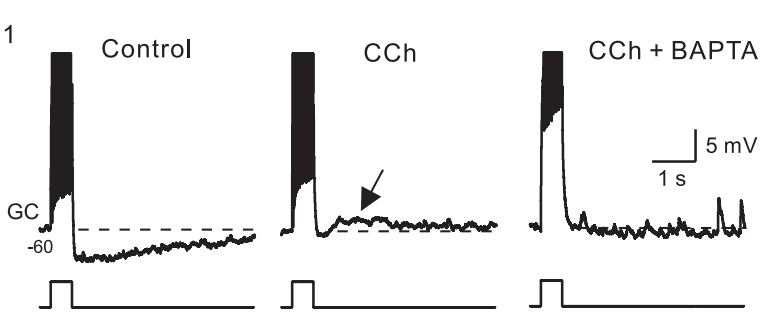

$\mathrm{B}_{2}$

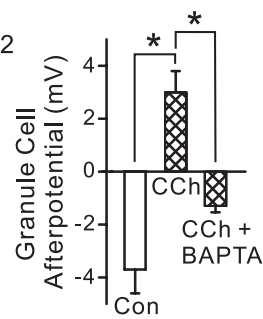

$\mathrm{C}_{1}$
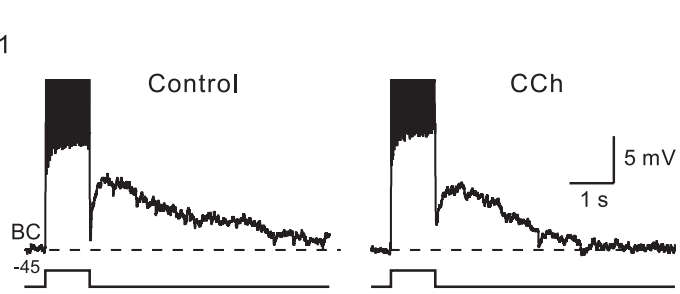

$\mathrm{C}_{2}$

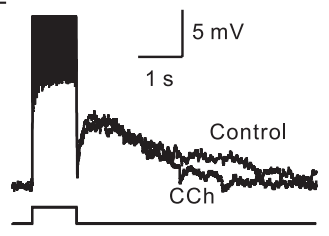

D
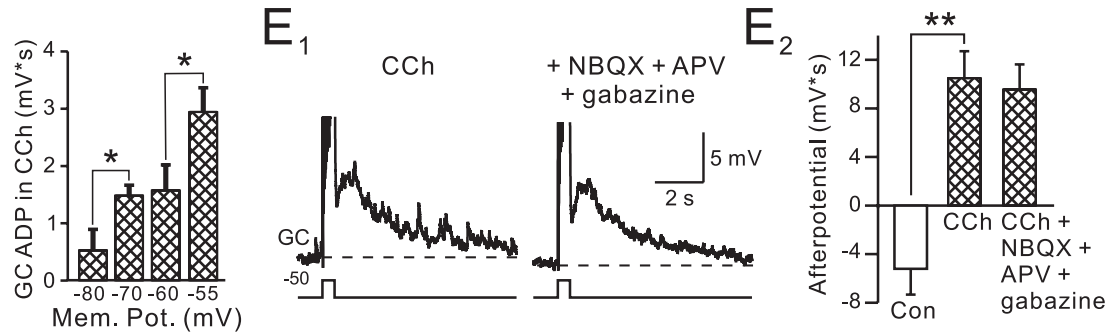

Figure 1. Cholinergic modulation of afterpotentials in granule cells. $\boldsymbol{A}$, Schematic diagram of olfactory bulb. Labels indicate glomerular layer (Glom), external plexiform layer (EPL), mitral cell layer (MCL), and granule cell layer (GCL). We recorded from both granule cells $(\mathrm{GC})$ and Blanes cells $(\mathrm{BC})$ in different experiments in this study. $\boldsymbol{B}_{1}, \mathrm{CCh}(2 \mu \mathrm{m})$ suppresses the afterhyperpolarization normally evoked by depolarizing steps in granule cells and reveals a BAPTA-sensitive afterdepolarization (arrow). Current step amplitude, $100 \mathrm{pA}$. The right panel is from a different experiment in which $10 \mathrm{~mm}$ BAPTA was added to the internal solution. The membrane potential is indicated below the trace. $\boldsymbol{B}_{2}$, Summary of the effects of $2 \mu \mathrm{m} C \mathrm{C}$ and BAPTA loading in 10 and 3 experiments, respectively. ${ }^{*} p<0.01$. Amplitudes were measured $1 \mathrm{~s}$ after step. $\boldsymbol{C}_{1}$, Carbachol had no effect on the afterdepolarization normally present in Blanes cells (100 pAstep). $\boldsymbol{C}_{\mathbf{2}}$, Overlap of control and CCh traces from $\boldsymbol{C}_{\mathbf{1}}$. D, ADPs in granule cells are voltage dependent. Responses are averaged from three experiments in $2 \mu \mathrm{m} C \mathrm{Ch}$. Current step amplitudes were adjusted to generate $13-15$ APs at each of the four membrane potentials (Mem. Pot.) tested. ${ }^{*} p<0.05$. $\boldsymbol{E}_{\boldsymbol{1}}$, Blockade of ionotropic glutamate and $\mathrm{AABA}_{\mathrm{A}}$ receptors with $5 \mu \mathrm{M} \mathrm{NBQX}, 25 \mu \mathrm{m}$ D-APV, and $10 \mu \mathrm{m}$ gabazine had no effect on the ADP response in granule cells treated with $2 \mu \mathrm{M} C \mathrm{Ch}$. Step amplitude, $50 \mathrm{pA}$. $\boldsymbol{E}_{2}$, Summary of four experiments with the receptor antagonists shown in $\boldsymbol{E}_{1}$. ${ }^{* *} p<0.05$. Action potentials are truncated in $\boldsymbol{B}, \boldsymbol{C}$, and $\boldsymbol{E}$.

type of GABAergic interneuron also located in the granule cell layer (Pressler and Strowbridge, 2006), normally responds to action potential bursts with ADPs that were unaffected by $\mathrm{CCh}$ (Fig. 1C) (control ADP amplitude, $7.4 \pm 0.9 \mathrm{mV}$; ADP amplitude in $\mathrm{CCh}, 6.6 \pm 1.0 \mathrm{mV} ; n=7 ; p>0.05)$. Bath application of the muscarinic receptor antagonist atropine also did not significantly effect the ADP response in Blanes cells (100.9 $\pm 8.1 \%$ of control; $n=3 ; p>0.05)$. Afterdepolarizations in granule cells were voltage dependent and were significantly smaller when elicited at hyperpolarized membrane potentials (Fig. 1D) (current step amplitudes adjusted to trigger the same number of APs at each mem- brane potential). Carbachol also generated a small inward current in granule cells that were manually voltage clamped at depolarized potentials (holding current at -54 $\mathrm{mV}$ decreased from $38.0 \pm 4.8$ to $22.5 \pm$ $3.7 \mathrm{pA} ; n=19 ; p<0.01)$. We did not explore the cellular basis for this effect, although it may reflect tonic activation of some Ca-activated processes (e.g., nonselective cation currents, see below) at depolarized membrane potentials. The effect of cholinergic receptor agonists on afterpotentials appeared to be a direct effect on granule cells as ADPs were unaffected by bath application of antagonists of ionotropic glutamate and GABA receptors [25 $\mu \mathrm{M}$ D-APV plus $5 \mu \mathrm{M}$ 2,3-dihyro-6-nitro7-sulfamoyl-benzo $(f)$ quinoxaline (NBQX) plus $10 \mu \mathrm{M}$ gabazine] (Fig. $1 E_{1}, E_{2}$ ). Afterdepolarizations in CCh-treated granule cells were blocked by the inorganic Ca channel antagonist $\mathrm{Cd}(200 \mu \mathrm{M})$. As shown in Figure 2A, Cd decreased the mean afterpotential amplitude after a $500 \mathrm{~ms}$ depolarizing step from $+4.1 \pm 0.7$ $\mathrm{mV}$ to $-0.4 \pm 0.7 \mathrm{mV}(p<0.01 ; n=5)$.

The sensitivity of the ADP response in CCh-treated rat granule cells to both BAPTA and Cd, and its voltage dependence, are consistent with a $\mathrm{Ca}$-activated nonselective cation current $\left(I_{\mathrm{CAN}}\right)$ (HajDahmane and Andrade, 1998, 1999; Hall and Delaney, 2002; Pressler and Strowbridge, 2006), an inward current suggested to underlie afterdepolarizations in both amphibian granule cells (Hall and Delaney, 2002) and rat olfactory bulb Blanes cells (Pressler and Strowbridge, 2006). We next tested this hypothesis by defining the effects of an $I_{\text {CAN }}$ blocker, partial Na substitution, and by artificially elevating free $\mathrm{Ca}$ in granule cells. We first examined the effect of flufenamic acid (FFA; $100 \mu \mathrm{M}$ ), a relatively nonselective $I_{\mathrm{CAN}}$ antagonist (Partridge and Valenzuela, 2000; Ghamari-Langroudi and Bourque, 2002), on the ADP in rat granule cells. As shown in Figure 2, $B_{1}$ and $B_{2}$, FFA reduced the ADP in granule cells from $7.7 \pm 2.8$ to $2.1 \pm 1.6 \mathrm{mV}(n=3 ; p<0.05 ; 15 \mathrm{~min}$ bath application) without abolishing $\mathrm{Na}$-based action potential firing. The partial blockade of the granule cell ADP by FFA is consistent with the partial antagonism of the $I_{\mathrm{CAN}}$-based ADP in Blanes cells reported previously (Pressler and Strowbridge, 2006).

Afterdepolarizations also could be triggered by Ca spikes evoked in the presence of TTX $(1 \mu \mathrm{M})$ and CCh $(2 \mu \mathrm{M})$ (Fig. $2 C)$. Reducing the driving force for $\mathrm{Na}$ ions by partial NMG substitution significantly reduced ADP responses evoked by Ca spikes from $2.2 \pm 0.9$ to $0.2 \pm 0.2 \mathrm{mV} \cdot \mathrm{s}(n=3 ; p<0.05)$, strongly suggesting that ADPs are mediated by Ca-activated, nonselective cation currents. The effects of NMG substitution on the ADP were reversible with reapplication of ACSF with 

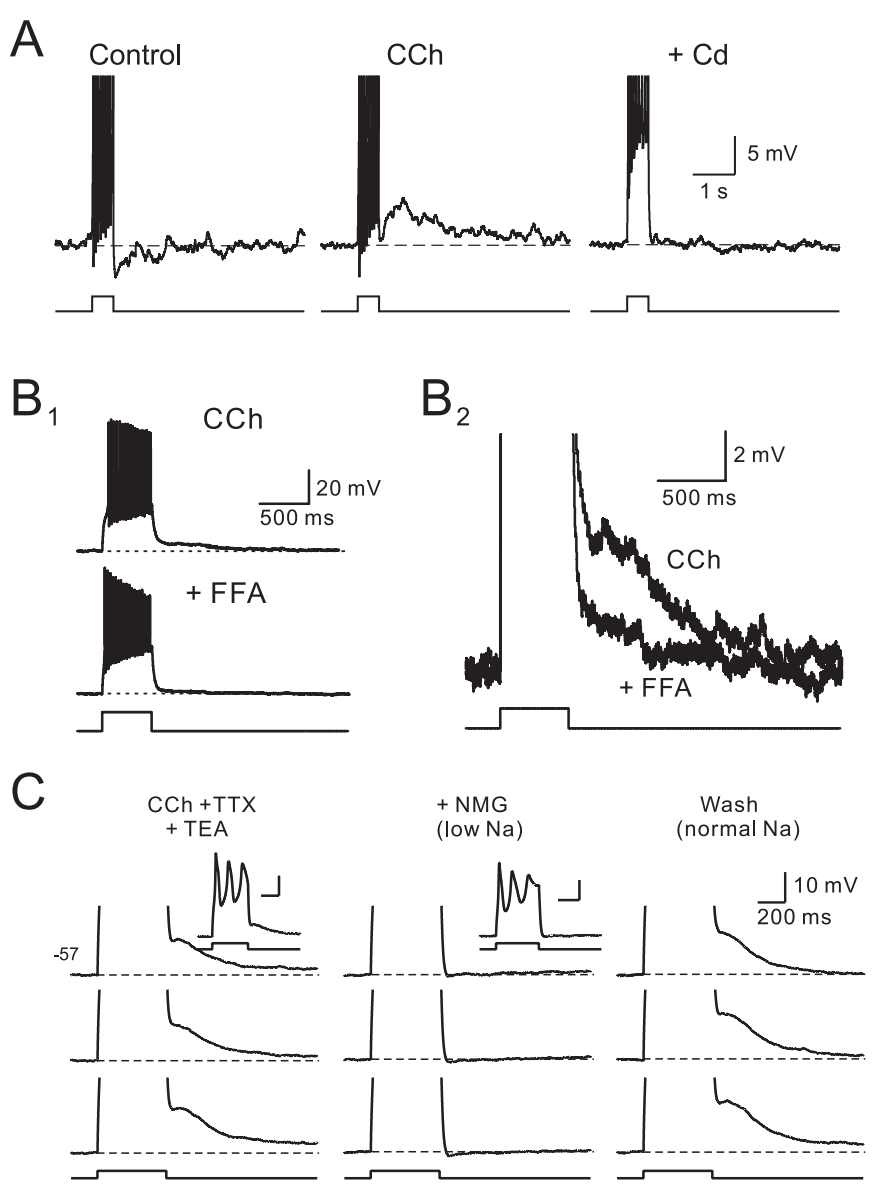
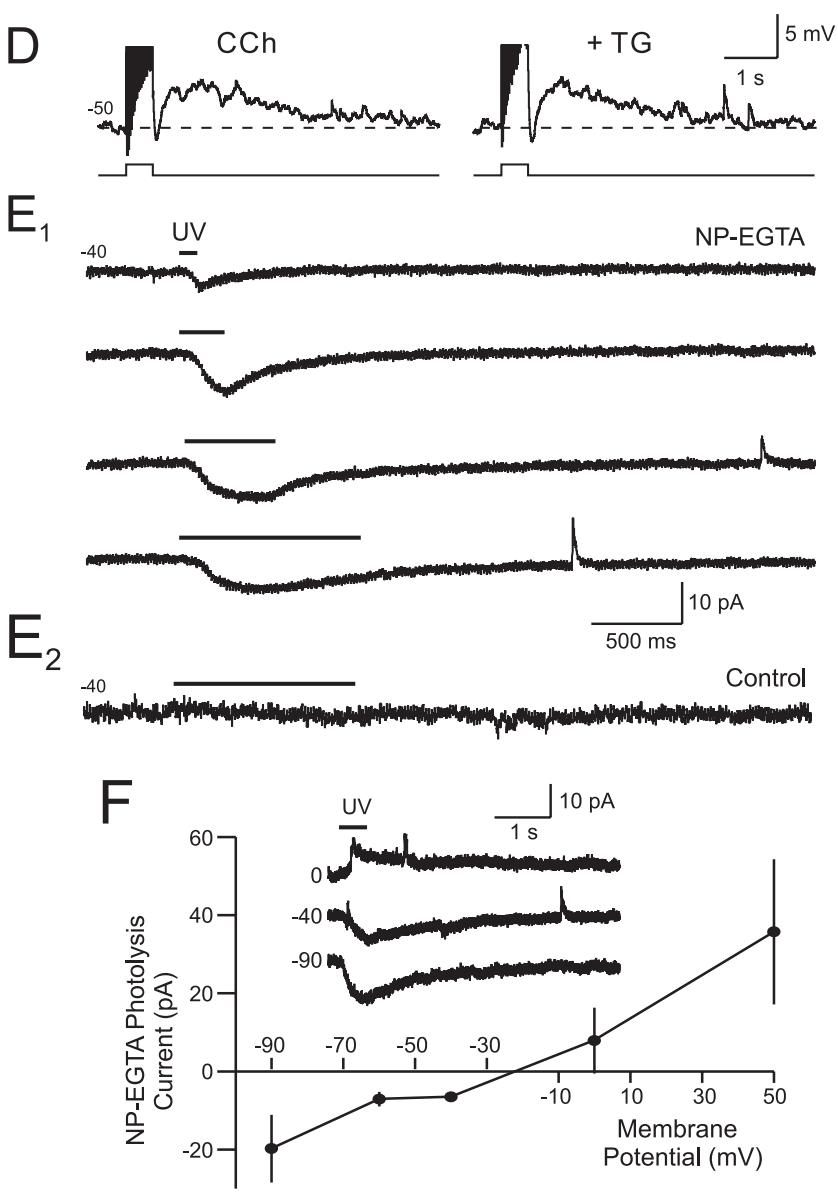

Figure 2. Mechanism of afterdepolarization in granule cells. $\boldsymbol{A}_{\boldsymbol{1}}$, Cadmium (Cd; $\left.200 \mu \mathrm{m}\right)$ abolishes the afterdepolarization evoked in granule cells by 25 pA depolarizing steps in $2 \mu \mathrm{m}$ CCh. $\boldsymbol{A}_{2}$, Summary of the effect of Cd on ADP amplitude. ${ }^{*} p<0.01$. $\boldsymbol{B}_{\boldsymbol{1}}$, Flufenamic acid (100 $\mu \mathrm{m}$ ) blocks the ADP in CCh. $\boldsymbol{B}_{\mathbf{2}}$, Enlargement of CCh and CCh + FFA responses. Action potentials truncated in $\boldsymbol{A}_{\boldsymbol{1}}$ and $\boldsymbol{B}_{2}$. C, ADPs evoked by Ca spikes in $2 \mu \mathrm{m}$ CCh, $1 \mu \mathrm{m}$ TTX, $25 \mathrm{~mm}$ TEA, $100 \mu \mathrm{m}$ 4-AP and $4 \mathrm{~mm}$ CsCl. Reducing the Na driving force by applying an ACSF solution containing 99 mm NMG reversibly blocked the ADP ("+NMG"). Responses to 90 pA steps are truncated to illustrate afterpotentials. Example responses in CCh and CCh + NMG conditions shown in the insets. $D$, Thapsigarin (TG; 10 $\mu \mathrm{m}$ ) did not reduce the ADP response in granule cells exposed to $2 \mu \mathrm{m}$ CCh (50 pA step). $\boldsymbol{E}_{\boldsymbol{1}}$, Photolyzing NP-EGTA ( 2 mm; added to the internal solution) evokes a graded inward current in voltage-clamped granule cells. Horizontal lines above each trace indicate UV exposure time $\left(100,250,500\right.$, and 1000 ms). $\boldsymbol{E}_{2}$, UV exposure by itself does not evoke an inward current in control granule cells that were not loaded with NP-EGTA. F, Uncaging response reversed polarity at approximately $-20 \mathrm{mV}$ (data from 5 experiments). The inset shows example responses recorded at $0,-40$, and $-80 \mathrm{mV}$.

normal Na ion concentrations. Afterdepolarization responses in granule cells were unaffected by bath application of ryanodine (from $4.0 \pm 1.2$ to $3.4 \pm 1.4 \mathrm{mV} \cdot \mathrm{s} ; n=4 ; p>0.05 ; 10$ $\mu \mathrm{M})$ and were slightly, but significantly, reduced by thapsigargin (from $6.8 \pm 1.3$ to $4.9 \pm 1.2 \mathrm{mV} \cdot \mathrm{s} ; n=5 ; p<0.05 ; 10 \mu \mathrm{M}$ ) (Fig. $2 D$ ), suggesting that most of this response is triggered by transmembrane Ca influx through voltage-gated Ca channels. Also consistent with the $I_{\mathrm{CAN}}$ hypothesis is the observation shown in Figure $2 \mathrm{E}, \mathrm{F}$ that uncaging $\mathrm{Ca}$ in granule cells by photolyzing NP-EGTA triggered graded inward currents at $-40 \mathrm{mV}(n=5)$ that reversed polarity at approximately -20 $\mathrm{mV}$ (0.1-1 s light exposure). In control experiments, $1 \mathrm{~s}$ duration UV light exposures failed to trigger inward currents in granule cells that did not contain NP-EGTA (Fig. $\left.2 E_{2}\right)(n=4)$. The inward current triggered by photolyzing NP-EGTA also was associated with a statistically significant decrease in input resistance (to $57.7 \pm 5.9 \%$ of control; $n=4 ; p<0.01$ ) measured by small amplitude hyperpolarizing test pulses. Together, these data suggest that the ADP response in CChtreated granule cells is attributable to a Ca-dependent increase in conductance associated with an $I_{\text {CAN }}$-like inward current.

\section{Pharmacology of afterpotential modulation in rat granule cells}

As shown above, activation of cholinergic receptors abolishes the afterhyperpolarization that normally follows brief depolarizations, revealing a latent afterdepolarization response. The ability of CCh to modulate afterpotentials in granule cells for many minutes (often $>15$ min in these experiments) suggests that muscarinic rather rapidly desensitizing nicotinic receptors are responsible for this effect. We confirmed that hypothesis directly by demonstrating that atropine $(5-10 \mu \mathrm{M})$ reversed CCh-induced afterpotential modulation ( $n=4$ cells) (data not shown). When applied by itself, $10 \mu \mathrm{M}$ atropine had no effect on the AHP response (response integral, $-4.2 \pm 0.6 \mathrm{mV} \cdot \mathrm{s}$ vs $-3.4 \pm 0.7 \mathrm{mV} \cdot$ $\mathrm{s}$ in atropine; $n=5 ; p>0.05)$. Bath application of atropine also prevented the CCh-induced AHP-to-ADP conversion $(-3.4 \pm$ $0.7 \mathrm{mV} \cdot \mathrm{s}$ before CCh vs $-3.1 \pm 0.5 \mathrm{mV} \cdot \mathrm{s}$ after CCh; $n=5 ; p>$ $0.05)$.

We next asked which subtype of muscarinic receptors was responsible for modulating afterpotentials in granule cells. Pirenzepine, a specific antagonist for $\mathrm{M}_{1}$ muscarinic receptors (Hammer et al., 1980) rapidly reversed the effects of CCh and restored 
A


B
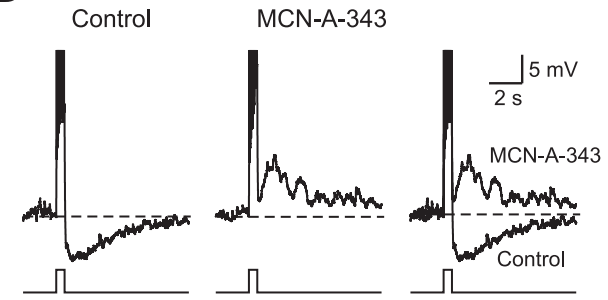
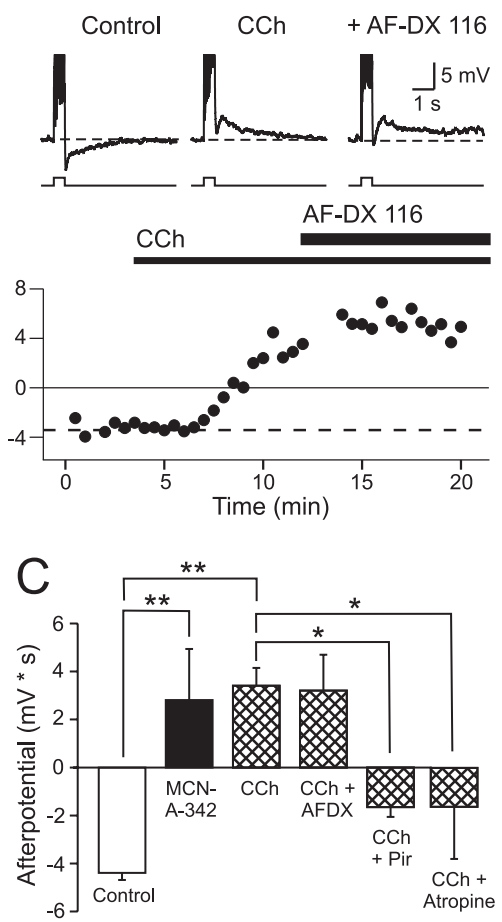

Figure 3. Pharmacology of afterpotential modulation in granule cells. $A$, Left, Plot of the afterpotential response integral in $\mathrm{CCh}(2 \mu \mathrm{m})$ and after bath application of the $\mathrm{M}_{1} \mathrm{mAChR}$ antagonist pirenzepine $(10 \mu \mathrm{M})$ and $\mathrm{CCh}$. Pirenzepine abolishes the ADP response evoked by $50 \mathrm{pA}$ depolarizing steps in $\mathrm{CCh}$ and restores the AHP normally present in granule cells under control conditions. Example traces shown above plot. Right, Bath application of the $\mathrm{M}_{2}$ mAChR antagonist AF-DX 116 (1 $\left.\mu \mathrm{m} ; 50 \mathrm{pA} \mathrm{step}\right)$ does not block the ADP in granule cells. $B$, Bath application of the $\mathrm{M}_{1}$ mAChR agonist MCN-A-343 (100 $\mu \mathrm{m} ; 50 \mathrm{pA}$ step) mimicked the effect of $C \mathrm{Ch}$ and converted the normal AHP response into an ADP. Control and MCN-A-343 traces are shown overlapped on right. Action potentials truncated in the step responses in $\boldsymbol{A}$ and $\boldsymbol{B}$ are shown. All example responses in $\boldsymbol{A}$ are from approximately $-55 \mathrm{mV}$; responses in $\boldsymbol{B}$ are from $-50 \mathrm{mV}$. C, Summary of the effects of atropine and $\mathrm{M}_{1}$ and $\mathrm{M}_{2}$ receptor agents on the afterpotential integral in granule cells. ${ }^{*} p<0.01 ;{ }^{* *} p<0.0001$.

the AHP evoked under control conditions (Fig. 3A, left) (afterpotential integral in $\mathrm{CCh}, 3.7 \pm 0.8 \mathrm{mV} \cdot \mathrm{s}$ vs $-1.9 \pm 0.5 \mathrm{mV} \cdot \mathrm{s}$ in $10 \mu \mathrm{M}$ pirenzepine plus CCh; $n=17$ and 5 , respectively; $p<$ 0.0001 .) We found a similar reduction in the ADP response (from $3.6 \pm 1.9$ to $-1.5 \pm 0.7 \mathrm{mV} \cdot \mathrm{s} ; n=3 ; p<0.05$; paired $t$ test) with $2 \mu \mathrm{M}$ pirenzepine. In contrast to these results, experiments using AF-DX 116, a specific antagonist of $\mathrm{M}_{2}$ receptors (Hammer et al., 1986), failed to reverse the CCh-induced modulation of afterpotentials in granule cells (Fig. $3 A$, right) (mean afterpotential integral in $1 \mu \mathrm{M}$ AF-DX 116 plus CCh, $3.6 \pm 1.7 \mathrm{mV} \cdot \mathrm{s} ; n=5)$. We also found that an agonist specific for $\mathrm{M}_{1}$ receptors, $\mathrm{MCN}-\mathrm{A}-343$ $(100 \mu \mathrm{M})$, mimicked the effects of CCh and revealed latent ADP responses in granule cells (Fig. $3 B$ ) (mean afterpotential integral in MCN-A-343, $3.2 \pm 2.4 \mathrm{mV} ; n=5$; significantly different from control, $p<0.0001)$. These results are summarized in Figure $3 C$ and suggest that CCh modulates afterpotentials in granule cells through direct actions on $\mathrm{M}_{1}$ receptors.

\section{Differential effects of low and high concentrations of CCh on granule cell discharges}

A previous report on cholinergic modulation of granule cell discharges found that relatively high concentrations of CCh $(50 \mu \mathrm{M})$ reduced the spontaneous firing rate of granule cells recorded in the cell-attached configuration (Castillo et al., 1999), a finding that appears to be in opposition to the results presented in this study using lower $(2 \mu \mathrm{M})$ concentrations of CCh. We have explored the possible basis for this difference by comparing the effects of 2 and $50 \mu \mathrm{M}$ CCh. We found that, at high concentra- tions, CCh can decrease apparent excitability but only indirectly [through depolarization block (DP)] rather than through a second postsynaptic cholinergic mechanism.

Figure $4 A$ illustrates that $2 \mu \mathrm{M}$ CCh can enhance excitability whereas $50 \mu \mathrm{M}$ CCh reduces the number of $\mathrm{Na}$-based action potentials evoked during a step depolarization. The underlying ADP response appears to be graded with CCh concentration and is larger in $50 \mu \mathrm{M}$ CCh than in $2 \mu \mathrm{M}$ CCh (Fig. $4 A$, arrows). In $50 \mu \mathrm{M}$ CCh, action potential amplitude decreases during the response to an $80 \mathrm{pA}$ step until no additional action potentials can be generated by the middle of the step response, presumably because of depolarization block from the large ADP response combined with the step depolarization itself. In contrast, action potential amplitude is maintained during the entire step response in 2 $\mu \mathrm{M}$ CCh (Fig. $4 B$ ). We also found that 2 $\mu \mathrm{M}$ CCh significantly reduced spike frequency adaptation (adaptation ratio, $0.76 \pm 0.09$ in control vs $0.91 \pm 0.05$ in CCh; $p<0.05 ; n=4$ ). Input resistance also was unaffected by $2 \mu \mathrm{M}$ CCh, but was significantly increased in $50 \mu \mathrm{M}$ CCh (Fig. $4 C_{1}$ ). The amplitude of the first two action potentials triggered by the step depolarization was unaffected by either 2 or $50 \mu \mathrm{M}$ CCh (Fig. $4 C_{2}$ ), suggesting that even high concentrations of CCh did not interfere with action potential generation per se. However, $50 \mu \mathrm{M}$ CCh, but not $2 \mu \mathrm{M}$ CCh, significantly reduced the amplitude of the third action potential evoked by the step depolarization (from $52.8 \pm 2.2 \mathrm{mV}$ in control to $30.2 \pm 6.7 \mathrm{mV}$ in $50 \mu \mathrm{M} \mathrm{CCh} ; p<0.01$ ).

These results suggest that high concentrations of CCh enhanced an ADP-like process that put granule cells into DP block during step responses, reducing their apparent excitability when tested using relatively large current steps. The underlying effects (blockade of the normal AHP response, recruitment of an ADP) appear similar after both 2 and $50 \mu \mathrm{M}$ CCh. Granule cells exposed to $50 \mu \mathrm{M}$ CCh that show an apparent decrease in excitability when tested with large-amplitude depolarizing steps show an increase in excitability when tested with weaker stimuli (Fig. $4 D_{1}$ ). Over a population of seven granule cells tested systematically, $2 \mu \mathrm{M} \mathrm{CCh}$ significantly increased the mean number of action potentials triggered by $60 \mathrm{pA}$ depolarizing steps to $183 \%$ of control (from $1.72 \pm 0.4$ to $3.14 \pm 0.6 ; p<0.05$ ). Elevating the concentration of CCh to $50 \mu \mathrm{M}$ further increased the number of action potentials evoked by these weak depolarizing steps to $263 \%$ of control (4.52 \pm 0.4 ; significantly different from control and from $2 \mu \mathrm{M}$ CCh; $p<0.05)$ (Fig. $4 D_{2}$ ).

We also tested whether bath application of CCh induces DP block in granule cells recorded in cell-attached conditions. In control slices, we did not observe spontaneous spiking in cellattached recordings from presumptive granule cells $(n=35)$, consistent with the relatively hyperpolarized membrane potentials of these neurons recorded under whole-cell conditions $(-74.3 \pm 1.6 \mathrm{mV} ; n=23)$. To assess the effect of CCh on spontaneous activity in granule cells, we attempted to induce sponta- 



Figure 4. Differential effects of low and high concentrations of CCh on granule cell step responses. A, High concentrations of CCh (50 $\mu \mathrm{m})$ increased the ADP amplitude (arrows) beyond the response recorded in $2 \mu \mathrm{m} C \mathrm{Ch}$ and decreased the duration of firing during the step response ( $80 \mathrm{pA}$ current step). Action potentials are truncated. $\boldsymbol{B}$, Step responses from the traces in $\boldsymbol{A}$ shown at faster sweep speeds. $C_{1}$, Summary of the effect of low and high concentrations of $\mathrm{CCh}_{\text {on }}$ granule cell input resistance. ${ }^{* *} p<0.01$. $\boldsymbol{C}_{2}$, Summary of the effects of low and high concentrations of $C_{C h}$ on the amplitude of the first three action potentials in the step response. ${ }^{* *} p<0.01$. ${ }_{1}$, Fifty micromolars $C(h$ increased the number of action potentials evoked by a relatively weak current step $(60 \mathrm{pA}) . \boldsymbol{D}_{2}$, Summary of the effects of 2 and $50 \mu \mathrm{m} C \mathrm{Ch}$ on granule cell responses to weak depolarizing steps (250 ms duration) that triggered $1-3$ spikes in control. ${ }^{*} p<0.05$; ${ }^{* * *} p<0.001$. $\boldsymbol{E}_{1}$, Cell-attached recording from a spontaneously active granule cell in elevated $\mathrm{KCI}(5 \mathrm{~mm}$ instead of $3 \mathrm{~mm})$ ACSF. Bath application of $2 \mu \mathrm{m}$ CCh initially decreased AP amplitudes and then, at $3.25 \mathrm{~min}$, abolished spiking. Spike frequency varied during CCh washing and occasionally became higher than in control conditions. Mean firing frequency is indicated above horizontal bars. Increasing bath CCh concentration to $50 \mu \mathrm{m}$ did not recover spiking activity (data not shown). $E_{2}$, Response to $15 \mathrm{pA}$ depolarizing current step after washout of CCh in whole-cell recording from the same neuron in $\boldsymbol{E}_{1} \cdot \boldsymbol{E}_{3}$, Reconstruction of the granule cell recorded in cell-attached $\left(\boldsymbol{E}_{1}\right)$ and whole-cell $\left(\boldsymbol{E}_{2}\right)$ conditions from multiple maximum intensity projections of two-photon image $z$-stacks. Olfactory bulb layers are indicated above the montage.

neous firing in 32 granule cells by elevating extracellular $[\mathrm{K}]$ or by depolarizing the cell through the membrane under the patch pipette. We evoked spontaneous spiking in six of these 32 cellattached recordings using these methods (two with passive depolarization and four by increasing extracellular $[\mathrm{K}]$ to $5 \mathrm{~mm}$ ). Carbachol abolished firing in all six cell-attached recordings (mean pre-CCh firing frequency, $9.9 \pm 2.0 \mathrm{~Hz}$ ) (Fig. $4 E_{1}$ ). Firing stopped in five of six cells tested in $2 \mu \mathrm{M}$ CCh in $4.8 \pm 0.9 \mathrm{~min}$ whereas the remaining neuron continued to fire (at 169\% of control frequency) at that concentration of $\mathrm{CCh}$, but then stopped firing in $3 \mathrm{~min}$ after the CCh concentration was increased to $50 \mu \mathrm{M}$. In the 5 recordings in which $2 \mu \mathrm{M}$ CCh abolished firing, increasing the concentration of CCh to $50 \mu \mathrm{M} \mathrm{did}$ not restore spontaneous discharges. Although we consistently observed a reduction in the amplitude of spikes recorded in the cell-attached mode as CCh was applied, we did not record a consistent increase in tonic firing. Rather, the firing became irregular, with occasional epochs of higher frequency discharges (Fig. $4 E_{1}$, horizontal bars), occurring before granule cells stopped firing. The transition from normal tonic firing to apparent DP block occurred rapidly $(1.8 \pm 0.5 \mathrm{~min})$. After breakthrough to the whole-cell recording mode, all six granule cells rested at depolar- ized membrane potentials $(>-35 \mathrm{mV})$ in the presence of $50 \mu \mathrm{M}$ $\mathrm{CCh}$, consistent with the hypothesis that firing stopped because of the membrane potential became depolarized enough to inactivate sufficient Na channels to prevent action potential generation. After CCh washout, all six neurons hyperpolarized and appeared to be granule cells based on their intrinsic electrophysiological properties (Fig. $4 E_{2}$ ). We also reconstructed the morphology of three of six neurons that stopped firing in CCh using two-photon imaging and confirmed that all three were spiny, axonless granule cells with apical dendrites directed toward the glomerular layer (Fig. $4 E_{3}$ ).

\section{Functional consequences of cholinergic modulation in granule cells}

We next attempted to define the functional effects of $M_{1}$ receptor-mediated modulation of afterpotentials in granule cells. Granule cells, like most cell types in the olfactory bulb, are subject to slow phasic excitation during sniffing (Macrides and Chorover, 1972; Cang and Isaacson, 2003; Margrie and Schaefer, 2003). We used a current stimulus composed of trains of $\alpha$ functions to mimic the natural excitatory drive onto granule cells when glutamatergic mitral and tufted cells are excited during 
sniffing (Charpak et al., 2001; Halabisky and Strowbridge, 2003; Balu et al., 2004; Balu and Strowbridge, 2007). When repeated at physiological sniffing frequencies, granule cell responses decreased substantially within trains of four or more $\alpha$ functions (Fig. $5 A$, top trace) $(2.5 \mathrm{~Hz})$. This behavior, recorded in individual granule cells in rat olfactory bulb slices, closely resembles the adaptation reported in granule cell responses recorded in vivo during actual sniffing in rodents (Cang and Isaacson, 2003). Response adaptation appears to be caused by intrinsic and not synaptic mechanisms in our brain slice experiments because blockade of ionotropic glutamate and GABA receptors did not affect this behavior (data not shown).

Activation of muscarinic receptors had two principal effects on these responses: it increased the total number of action potentials evoked by the stimulus train and shifted the proportion of spikes triggered by each $\alpha$ function in the train. As shown in Figure $5 A$, CCh increased the excitability of granule cells to both slowly varying stimuli (trains of $\alpha$ functions; $14.3 \pm 1.3$ spikes/ train in control to $29.4 \pm 6.6$ spikes/train in $2 \mu \mathrm{M} \mathrm{CCh} ; p<0.05$; $n=8$ ) and to simple step depolarizations (inset). Carbachol also increased the percentage of total spikes trigged by the last $\alpha$ function (from $21.5 \pm 1.6 \%$ in control to $27.4 \pm 1.5 \%$ in CCh; $p<$ $0.05 ; n=8)$ and decreased the percentage triggered by the first $\alpha$ function (from $27.2 \pm 1.7 \%$ to $20.6 \pm 1.5 \% ; n=8 ; p<0.01$ ). These effects were observed consistently in all eight granule cells tested and could be reversed by atropine $(5 \mu \mathrm{M} ; n=4)$ (Fig. $5 B)$. The results from these experiments are summarized in Figure 5, $\mathrm{C}_{1}$ and $\mathrm{C}_{2}$.

Carbachol also phase-advanced spike firing in granule cells activated with $5 \mathrm{~Hz}$ sine wave stimuli (mean latency decreased from $84.0 \pm 4.4 \mathrm{~ms}$ in control to $70.3 \pm 7.0 \mathrm{~ms}$ in $2 \mu \mathrm{M} \mathrm{CCh} ; n=$ $3 ; p<0.05$ ) (Fig. $5 D_{1}$ ) and the first spike triggered by phasic $\alpha$ functions (by $4.2 \pm 5.1,10.9 \pm 5.6,18.0 \pm 8.1$ and $18.9 \pm 6.6 \mathrm{~ms}$ for $\mathrm{SEPSP}_{1-4}$; shift in latency statistically significant for $\mathrm{SEPSP}_{2-4}$; $p<0.05)$. Consistent with a previous report of latency shifts after muscarinic receptor activation in hippocampal interneurons (Lawrence et al., 2006), we observed a parallel reduction in action potential jitter in oscillating granule cells in CCh (from $8.7 \pm 1.3$ to $6.1 \pm 0.9 \mathrm{~ms} ; n=3 ; p<0.05)$ (Fig. $5 D_{2}$ ), suggesting that one function of cholinergic receptors in the rat olfactory bulb may be to modulate the reliability of spike timing in interneurons.

Our findings suggest that the adaptation normally observed in granule cell responses to repetitive stimuli may result, at least in part, from the effects of $\mathrm{M}_{1}$ receptor-sensitive afterhyperpolarizations evoked by the initial responses. This hypothesis explains why $M_{1}$ receptor activation increases both granule cell excitability and the proportion of spikes triggered by late stimuli in the train. Presumably, many of the spikes triggered by late stimuli in the train are caused by the combined depolarization from the intrinsic ADP response and the phasic excitatory input.

To test this hypothesis, we defined the effect of cholinergic receptor activation on synaptically evoked responses recorded in granule and mitral cells. In these experiments we used trains of on-beam glomerular stimuli to activate subpopulations of mitral and tufted cells to disynaptically excite granule cells. As shown in Figure $6 A_{1}$, trains of glomerular stimuli (at $2.5 \mathrm{~Hz}$ ) typically elicit short-duration discharges ( $0-2$ spikes) immediately after each shock in cell-attached recordings from granule cells. Bath application of CCh $(2 \mu \mathrm{M})$ potentiated these short-latency responses and facilitated prolonged discharges that outlasted the stimulus train by several hundred milliseconds. Over the course of $10 \mathrm{ex}-$ periments, CCh tended to increase slightly the number of spikes triggered by the first stimuli (from $1.6 \pm 0.5$ to $3.4 \pm 1.1$ ) al-
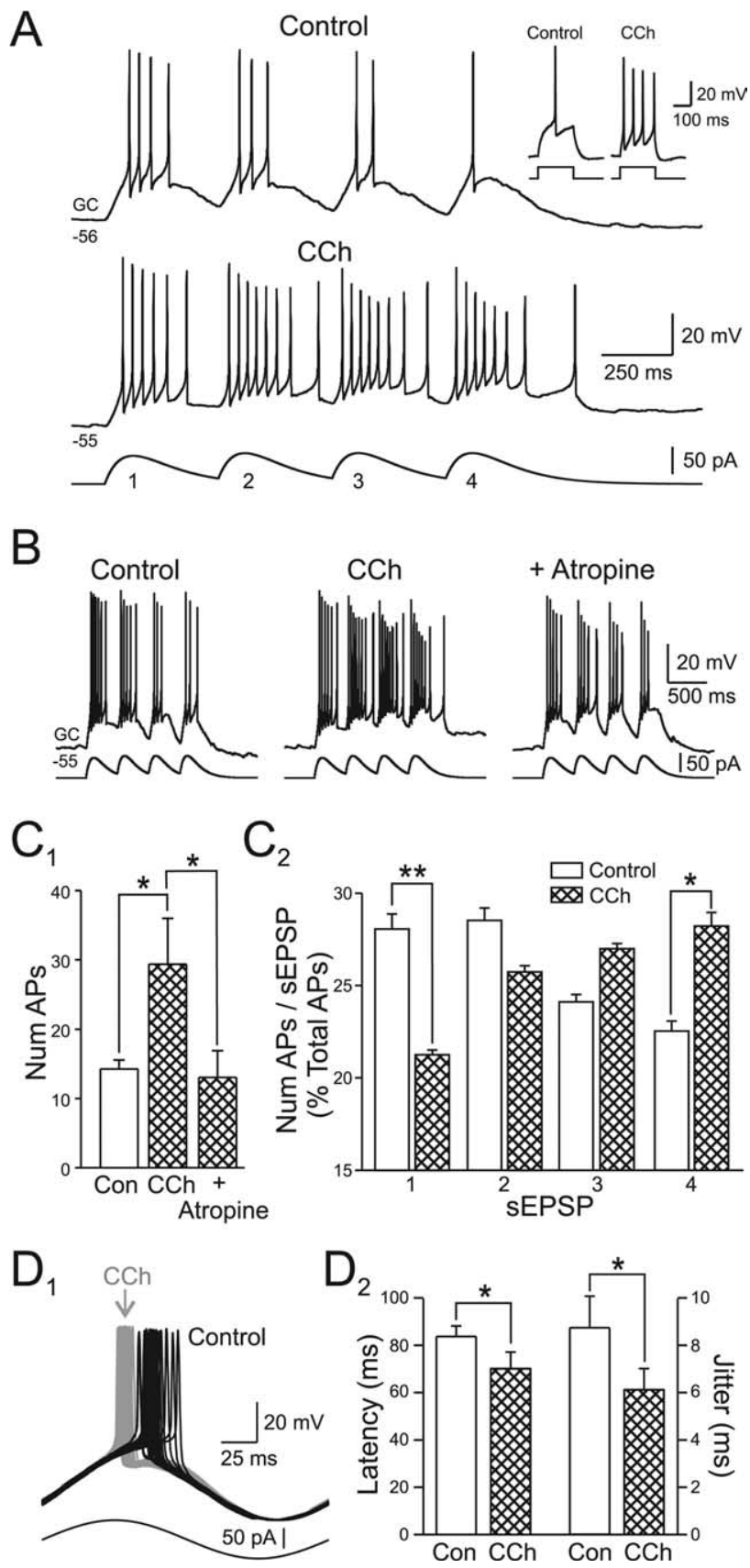

Figure 5. Muscarinic receptor activation prolongs granule cell responses to phasic excitatory input. $\boldsymbol{A}$, Granule cell responses to a train of four simulated EPSPs (sEPSP; $\alpha$ function; tau $=100$ $\mathrm{ms}$ ) are increased in $\mathrm{CCh}(2 \mu \mathrm{m})$. The inset shows the effect of CCh on the step response recorded in the same granule cell. $\boldsymbol{B}$, Bath application of $5 \mu \mathrm{m}$ atropine reversed the facilitating effect of CCh. $\boldsymbol{C}_{1}$, CCh significantly increased the total number of action potentials evoked by the four sEPSP train. This effect was abolished by $5 \mu \mathrm{m}$ atropine. ${ }^{*} p<0.05 . \boldsymbol{C}_{2}$, $\mathrm{CCh}$ also decreased the percentage of action potentials evoked by the first sEPSP and increased the percentage triggered by the last SEPSP. ${ }^{*} p<0.05 ;{ }^{* *} p<0.01$. The number of action potentials calculated over windows of $400 \mathrm{~ms}$ aligned to the onset of each SEPSP. $D_{1}$, Bath application of $2 \mu \mathrm{m}$ CCh reduced the latency granule cells discharge in response to a $5 \mathrm{~Hz}$ sine wave stimulus and decreased latency jitter. Control responses in black, responses in CCh shown in gray. $\boldsymbol{D}_{2}$, Summary of $2 \mu \mathrm{M}$ CCh-induced changes in AP latency and jitter (SD of latency) after $5 \mathrm{~Hz}$ sine wave stimulation in three experiments. ${ }^{*} p<0.05$.

though this change was not statistically significant. More robust was the effect on the number of spikes evoked in the $3 \mathrm{~s}$ period immediately after the train, which increased from $2.2 \pm 1.1$ in control to $8.5 \pm 3.9$ in CCh; $p<0.05$; paired $t$ test). 
$A_{1}$

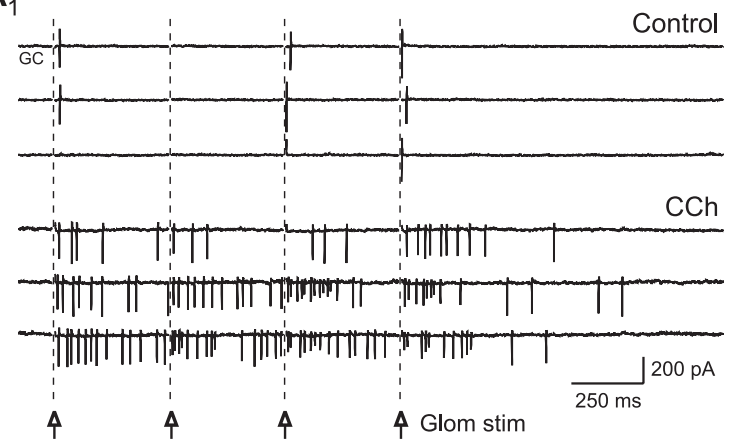

$\mathrm{A}_{2}$

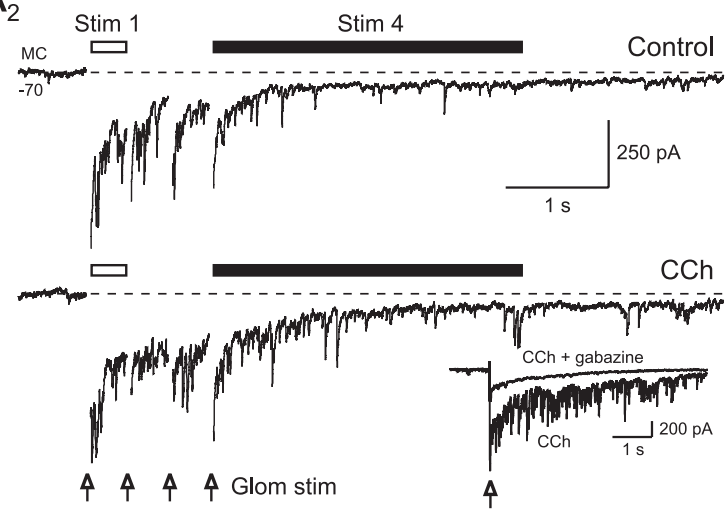

$\mathrm{B}_{1}$

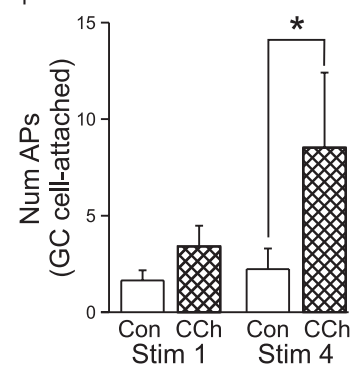

C

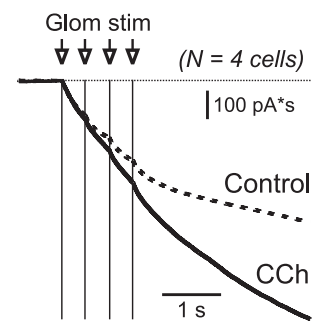

$\mathrm{B}_{2}$

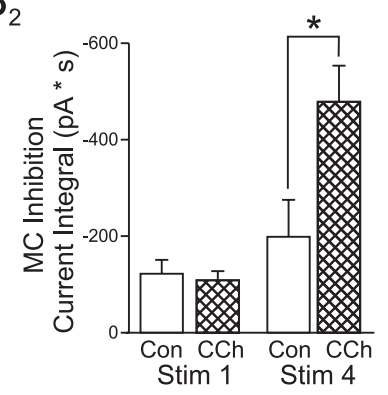

D

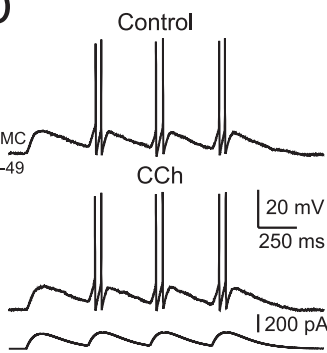

E

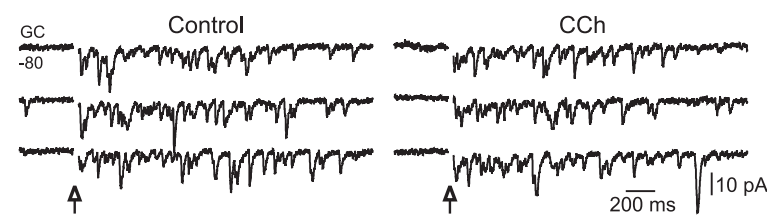

Figure 6. Muscarinic receptor activation potentates synaptically evoked inhibition onto mitral cells. $\boldsymbol{A}_{\boldsymbol{1}}$, Cell-attached granule cell responses to a train of four glomerular layer stimuli (upward arrows; $400 \mathrm{~ms}$ interval; $100 \mu \mathrm{A}$ ) are increased after bath application of CCh (2 $\mu \mathrm{m})$. Three consecutive responses shown in control conditions and in CCh. $\boldsymbol{A}_{2}$, Mitral cell responses to a similar train of glomerular shocks also are potentiated by $\mathrm{CCh}_{\text {. }}\left(\mathrm{GABA}_{\mathrm{A}}\right.$ receptor-mediated currents are inward in these experiments because of the $\mathrm{CsCl}$-based internal solution.) The inset shows most of the response to a single glomerular shock in CCh is blocked by $10 \mu \mathrm{m}$ gabazine (different mitral cell than $\boldsymbol{A}_{2}$ ). $\boldsymbol{B}$, Summary of the selective potentiation of the late response (Stim 4; timing indicated solid bar above traces in $\boldsymbol{A}_{2}$ ) by $C\left(h\right.$ with no significant increase in the early response (Stim 1 ; open bar) for both cell-attached granule cell recordings $\left(\boldsymbol{B}_{\mathbf{1}}\right)$ and mitral cell intracellular responses $\left(\boldsymbol{B}_{\mathbf{2}}\right) .{ }^{*} p<$ 0.05. C, Cumulative plot of inhibitory responses in four mitral cells to glomerular shocks (Glom stim) before (dashed line) and after $2 \mu \mathrm{m}$ CCh (solid line). $\boldsymbol{D}$, Bath application of $2 \mu \mathrm{m}$ CCh had no effect on mitral cell intrinsic physiology assessed by responses to slow, phasic stimuli ( $4 \alpha$ functions, tau $=100 \mathrm{~ms}$; interval, $400 \mathrm{~ms}$ ) or depolarizing step stimuli (data not shown). $\boldsymbol{E}$, Carbachol ( $2 \mu \mathrm{m}$ ) also had no effect on the barrage of glutamatergic EPSCs evoked in voltage-clamped granule cells after glomerular stimulation. Three consecutive responses are shown in each condition.

Because mitral cells receive monosynaptic inhibition from GABAergic granule cells, we next sought to test whether CCh also modulated the inhibitory drive onto these neurons in a similar manner that disproportionately facilitated late responses. In these experiments, we recorded from mitral cells under voltageclamp conditions that maximized our ability to detect inhibitory synaptic inputs (CsCl-based internal solution; cells held at -70 $\mathrm{mV}$ ). As shown in Figure $6 A_{2}$, trains of glomerular stimuli similar to those used in the granule cell experiments $(2.5 \mathrm{~Hz})$ caused large inward currents because of summating synaptic currents. These responses were due primarily to $\mathrm{GABA}_{\mathrm{A}}$ receptor-mediated IPSCs because they were blocked by gabazine $(10 \mu \mathrm{M})$ (Fig. $6 A_{2}$, inset). As shown in Figure $6 A_{2}$, the magnitude of synaptic inhibition onto mitral cells strongly adapts with repetitive stimuli, paralleling the adaptation in the granule cell responses to phasic current injection (Fig. 5A-C). Because the summating synaptic responses triggered by each stimuli overlapped, we quantified this effect by comparing the late response ( $3 \mathrm{~s}$ window, beginning immediately after the stimulus train) to the initial response (400 ms window after the first stimuli). Bath application of CCh $(2$ $\mu \mathrm{M})$ did not change the synaptic inhibition recorded in mitral cells after the first glomerular stimulation $(-122.2 \pm 28.8 \mathrm{nA} \cdot \mathrm{s}$ in control vs $-108.6 \pm 19.0 \mathrm{nA} \cdot \mathrm{s}$ in CCh; $n=4 ; p>0.05)$ but increased by more than twofold the inhibition recorded in the post-train window $(-198.4 \pm 76.8 \mathrm{nA} \cdot \mathrm{s}$ in control to $-478.4 \pm$
$75.1 \mathrm{nA} \cdot \mathrm{s}$ in $\mathrm{CCh} ; p<0.05 ; n=4)$. These results are summarized in Figure $6, B_{1}$ and $B_{2}$, and are consistent with the same underlying cholinergic effect: a reduction in the normal AHP present in granule cells and a concomitant facilitation of an afterdepolarization response that preferentially increases granule cell activity during late responses in sniffing-like stimulus trains. The time course of mitral cell inhibition evoked by stimulus trains is shown as bar graphs in Figure 6, $A_{2}$ and $B_{2}$, and as cumulative current integral plots in Figure 6C.

The increase in late inhibition likely reflects, at least in part, the preferential increase in late firing in granule cells responses to glomerular stimulus trains because neither mitral cell intrinsic responses nor the excitatory input to granule cells after glomerular stimulation were affected by $2 \mu \mathrm{M}$ CCh. We assessed the intrinsic properties of mitral cells by recording responses to either simple depolarizing step stimuli (input resistance, $208.7 \pm$ 36.1 in control vs $204.0 \pm 34.1 \mathrm{M} \Omega$ in CCh; AP threshold, $-33.4 \pm 2.3$ vs $-31.8 \pm 2.8 \mathrm{mV}$; spike AHP amplitude, $-10.7 \pm$ $1.1 \mathrm{vs}-10.2 \pm 1.6 \mathrm{mV} ; n=5$ cells for each test; all differences not significant; $p>0.05)$ or trains of slow, phasic simulated EPSPs $(n=5)$ (Fig. 6D) (Balu et al., 2004). Low concentrations of CCh also did not affect the disynaptic barrages of glutamatergic EPSCs recorded in voltage-clamped granule cells after glomerular stimulation (mean current integral for the initial $100 \mathrm{~ms}$ after stimulation, $-656 \pm 150 \mathrm{pA} \cdot \mathrm{ms}$ in control vs $-722 \pm 300 \mathrm{pA} \cdot \mathrm{ms}$ in 

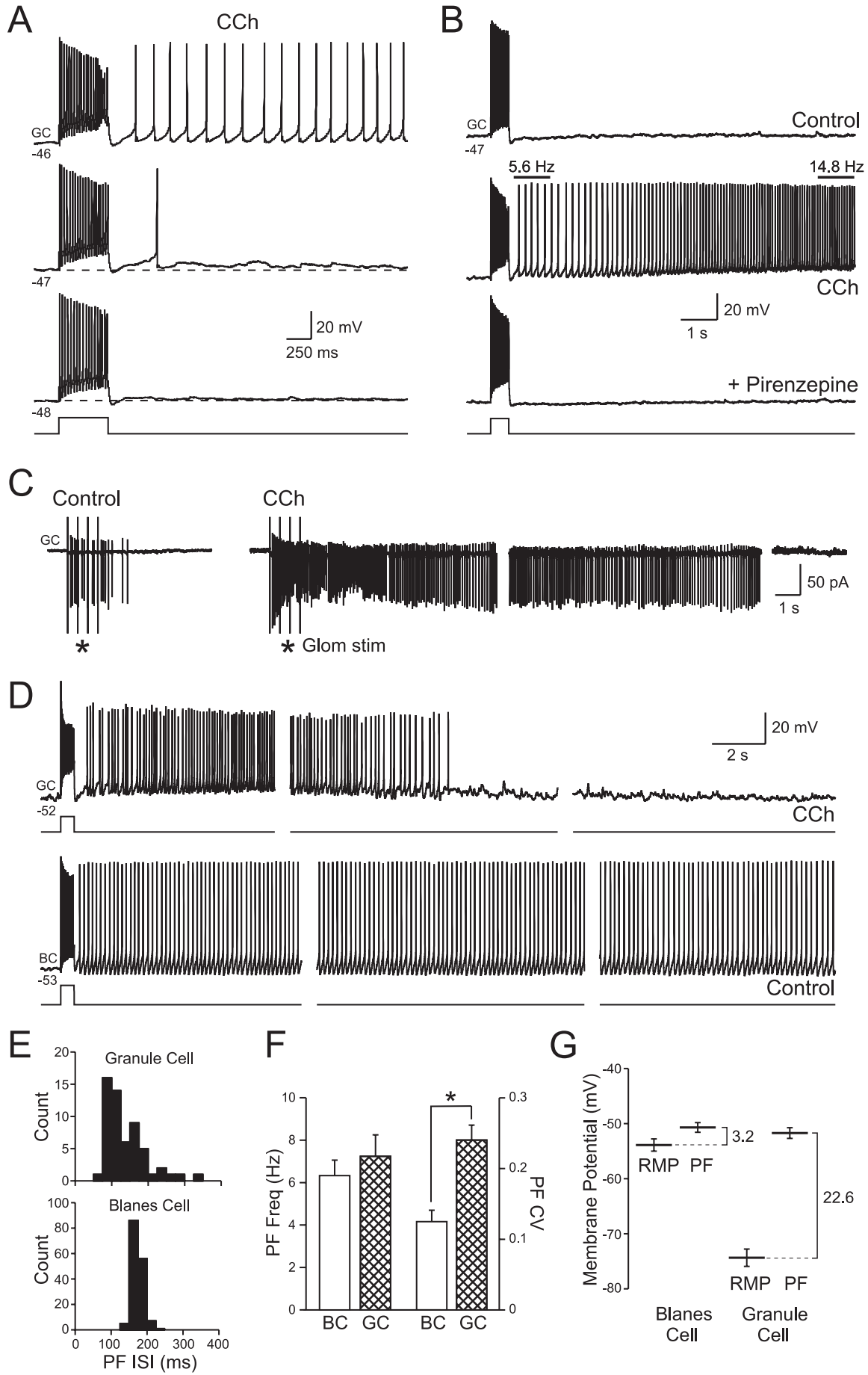

Figure 7. Persistent activity in granule cells after muscarinic receptor activation. $A$, Depolarizing granule cells slightly (from -48 to $-46 \mathrm{mV}$ ) converts the step-evoked ADP response into a prolonged action potential discharge. Responses to $50 \mathrm{pA} \mathrm{steps}$

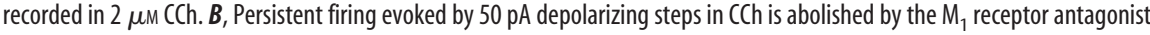
pirenzepine $(10 \mu \mathrm{m})$. Granule cell firing frequency was not constant and increased threefold during the response shown in the middle panel. C, Moderate intensity glomerular layer stimulation ( $4 \times 100 \mu \mathrm{A}$; $400 \mathrm{~ms}$ interval) triggered spiking in a cellattached granule cell recording. Bath application of $\mathrm{CCh}(2 \mu \mathrm{M})$ converted this transient response into a prolonged discharge that lasted $>40$ s. Gaps between consecutive sweeps shown were 20 s. $D$, Comparison of the persistent firing modes of granule cells (GC; top traces; recorded in $2 \mu \mathrm{M}$ CCh; $80 \mathrm{pA}$ step) and Blanes cells (BC; bottom traces; recorded under control conditions; $120 \mathrm{pA}$ step). Both cells held at approximately the same membrane potential and stimulated with $500 \mathrm{~ms}$ depolarizing steps. Gaps between consecutive sweeps shown were $10 \mathrm{~s}$ for the $\mathrm{GC}$ and 20 s for the $\mathrm{BC}$. The same voltage and time calibration for granule and Blanes cell recordings was used. $\boldsymbol{E}$, Histograms of the interspike intervals in the response after the depolarizing steps (PF ISI) in the granule and Blanes cells shown in $\boldsymbol{D}$. $\boldsymbol{F}$, Summary of persistent firing frequency (PF Freq) and the coefficient of variation of the instantaneous firing frequency (PF CV) for granule cells in CCh and Blanes cells in control conditions. ${ }^{*} p<0.05$. G, Summary of the differences between the RMP and persistent firing threshold (PF) for Blanes and granule cells.
$2 \mu \mathrm{M}$ CCh; $n=4 ; p>0.05$ ) (Fig. $6 E$ ), suggesting that the facilitated discharges shown in Figure $6 A_{1}$ reflected the increased excitability of granule cells in CCh.

Quasipersistent firing in granule cells

The ability of a neuron to generate afterdepolarizations is often associated with intrinsically stable persistent firing modes (Egorov et al., 2002). In the olfactory bulb, Blanes cells generate robust ADPs and can fire persistently for many minutes (Pressler and Strowbridge, 2006). As shown in the present study, the ADP response in Blanes cells does not appear to be modulated by cholinergic receptors and is present under basal conditions in acute brain slices. A subpopulation of pyramidal neurons in entorhinal cortex (Egorov et al., 2002) can fire persistently, but only after muscarinic receptor stimulation, which converts the AHP response normally recorded under resting conditions into an ADP. The ability of cholinergic input to convert AHP to ADP responses in entorhinal neurons appears to be the closest parallel to our findings regarding granule cells in the olfactory bulb.

Given these precedents, we next sought to test whether granule cells in CChtreated slices could fire persistently. We initially tested whether short step depolarizations could elicit prolonged periods of firing in granule cells exposed to $2 \mu \mathrm{M}$ CCh. As shown in Figure $7 A$, slight changes in the baseline membrane potential (from -46 to $-48 \mathrm{mV}$ ) dramatically affected the responses of granule cells to step depolarizations. At $-46 \mathrm{mV}$, this stimulus generated a prolonged discharge. The high sensitivity of step-evoked discharges to resting membrane potential was not caused by the voltage dependence of inward currents through NMDARs because these discharges were insensitive to D-APV $(25 \mu \mathrm{M})$ (data not shown). However, the ability to generate prolonged discharges that outlast the step depolarization was dependent on $M_{1}$ receptor activation. The same step depolarization that triggered prolonged discharges in CCh evoked simple afterhyperpolarization responses in control conditions and when $\mathrm{M}_{1}$ receptors were antagonized by pirenzepine (10 $\mu \mathrm{M})$ (Fig. 7B).

Unlike the constant frequency firing mode present in Blanes cells, the discharge frequency in CCh-treated granule cells varied within each response. In the example shown in Figure $7 B$, firing frequency increased nearly threefold in the first $7 \mathrm{~s}$. When stimulated near $(\sim 5 \mathrm{mV})$ firing threshold, CCh-treated granule cells gen- 
erated prolonged discharges that lasted at least $10 \mathrm{~s}$ with a characteristic peak in firing frequency several seconds after onset in both cell-attached (Fig. $7 C)(n=4)$ and whole-cell granule cell recording modes (Fig. $7 D)(n=19)$. The ability of synaptic inputs to trigger prolonged discharges in granule cells recorded in the cell-attached configuration (mean duration, $36.8 \pm 8.7 \mathrm{~s}$; mean frequency, $11.1 \pm 2.2 \mathrm{~Hz} ; n=4$ for both tests) (Fig. 7C) argues that this phenomenon is not caused by an artifact associated with intracellular recordings. Figure $7 D$ illustrates the differences in persistent firing modes between Blanes cells and CChtreated granule cells evoked by similar step depolarization stimuli. The prolonged discharges recorded in intracellularly granule cells typically lasted for 2 min (mean, $2.0 \pm 1.4 \mathrm{~min} ; n=$ 6 ) whereas persistent firing in Blanes was maintained for $16.5 \pm$ $5.1 \mathrm{~min}$ in whole-cell recording conditions $(n=9$; significantly different from granule cells; $p<0.05$ ). Although the average firing frequencies in granule and Blanes cell discharges were similar $(6.3 \pm 0.7 \mathrm{~Hz}$ in Blanes cells and 7.2 $\pm 1.0 \mathrm{~Hz}$ in granule cells $)$, the variation in instantaneous firing frequencies was significantly higher in discharges recorded from granule cells than Blanes cells (mean instantaneous firing frequency coefficient of variation, $0.24 \pm 0.08$ for granule cells vs $0.12 \pm 0.05$ for Blanes cells; $n=13$ and 11 respectively; $p<0.001$ ) (Fig. $7 E, F)$. Because of their relatively short duration and high variability in firing frequency, we have termed these granule cell discharges "quasipersistent firing" to differentiate them from the tonic persistent firing modes reported in Blanes (Pressler and Strowbridge, 2006) and entorhinal cells (Egorov et al., 2002). Both persistent and quasipersistent firing modes appear to be autonomous intrinsic responses because they greatly outlast the depolarizing inputs that trigger them (Fig. 7D).

Although both granule and Blanes cells had similar thresholds for triggering prolonged discharges when tested with short depolarizing steps $(-51.7 \pm 1.0 \mathrm{mV}$ and $-50.7 \pm 0.9 \mathrm{mV}$, respectively; $n=15$ and 23), the resting membrane potential of CChtreated granule cells was much further from this threshold than the resting membrane potential (RMP) of Blanes cells (Fig. 7G). Blanes cells rest at $-53.9 \pm 1.1 \mathrm{mV}$, only $3.2 \mathrm{mV}$ from their persistent firing threshold, whereas granule cells in CCh-treated slices rest at $-74.3 \pm 1.6 \mathrm{mV}, 22.6 \mathrm{mV}$ from their discharge threshold. These results suggest that granule cells require larger depolarizations to trigger autonomous discharges than do Blanes cells.

\section{Discussion}

In this study, we sought to define the postsynaptic response of granule cells to muscarinic receptor stimulation. We found that activation of $M_{1}$ receptors on granule cells coordinately eliminated the AHP response that normally follows discharges in these neurons and revealed a latent afterdepolarization. When held near firing threshold, the CCh-induced ADP response enabled granule cells to enter a quasipersistent firing mode that maintained firing for several minutes after the depolarizing stimulus. Through these mechanisms, cholinergic inputs can potentiate granule cell discharges and mitral cell inhibition and regulate the degree of adaptation that granule cells exhibit after repetitive stimulation.

\section{Cholinergic inputs to the olfactory bulb}

The majority of the cholinergic innervation to the olfactory bulb arises from projecting neurons in the nucleus of the HDB in the basal forebrain (Macrides et al., 1981; Luskin and Price, 1983; Zaborszky et al., 1986). Although the cholinergic projection to the bulb terminates in most layers, it is densest in the internal plexiform and glomerular layers (Halasz and Greer, 1993; Kasa et al., 1995) and appears to target primarily interneurons (Nickell and Shipley, 1988; Kunze et al., 1991; Kasa et al., 1995). Both $M_{1}$ and $\mathrm{M}_{2}$ muscarinic receptor subtypes are highly expressed in many layers within the olfactory bulb, including the granule cell layer (Le Jeune et al., 1995, 1996).

Chemical lesions of HDB neurons increases behavioral generalization between similar odorants (Linster et al., 2001b) whereas systemic injections of physostigmine, a cholinesterase inhibitor, enhance olfactory discrimination between similar odorants (Doty et al., 1999). However, the interpretation of these results is complicated by the complex projection patterns of HDB neurons, which include cortical targets as well as the olfactory bulb (Wilson et al., 2004). Direct injections of muscarinic receptor antagonists into the olfactory bulb impairs short-term olfactory memory but does not appear to greatly effect olfactory discrimination (Ravel et al., 1994). A previous study (Mandairon et al., 2006) confirmed that direct infusion of muscarinic receptor antagonists into the olfactory bulb reduces, but does not abolish, a rat's ability to perform an olfactory discrimination test. Together, these results point to a role for muscarinic receptor-mediated signaling in the olfactory bulb that relates predominately to short-term plasticity, rather than an essential role in encoding odorant-specific mitral cell firing patterns.

\section{Cellular mechanism of postsynaptic cholinergic response}

The changes in granule cell intrinsic responses we report are likely to be mediated by $\mathrm{M}_{1}$ receptors located directly on granule cell bodies or dendrites. The ability of muscarinic receptor agonists to affect afterpotentials in granule cells after ionotropic receptors are blocked (with D-APV, NBQX, and gabazine) argues that this modulation of intrinsic currents is triggered by receptors located on the granule cell itself, and not indirectly through muscarinic receptor-mediated activation of another neuronal cell type. Postsynaptic location distinguishes this effect from the previously documented effects of muscarinic receptors functioning presynaptically to modulate transmitter release in the olfactory bulb (Buckley et al., 1988; Le Jeune et al., 1995, 1996; Crespo et al., 2000; Ghatpande et al., 2006). The ability of atropine, a broad spectrum muscarinic receptor antagonist, as well as pirenzepine, a specific $M_{1}$ receptor antagonist, to block CCh-induced effects is consistent with assignment of these responses to $M_{1}$ receptors. Also consistent with this hypothesis is the ability of MCN-A-343, an $\mathrm{M}_{1}$ receptor agonist, to mimic the effect of $\mathrm{CCh}$ on granule cells and the inability of AF-DX 116, an $\mathrm{M}_{2}$ receptor antagonist, to reverse CCh's action.

The most likely cellular mechanism responsible for the afterdepolarization response is the Ca-activated nonselective cation current $\left(I_{\text {CAN }}\right)$. Previous reports have implicated $I_{\text {CAN }}$ in afterpotentials in hippocampal interneurons (McQuiston and Madison, 1999; Lawrence et al., 2006), pyramidal cells (Cole and Nicoll, 1983; Fraser and MacVicar, 1996) and the entorhinal cortex (Egorov et al., 2002), as well as Blanes cells in the olfactory bulb (Pressler and Strowbridge, 2006). The sensitivity of the ADP response to blockade of intracellular $\mathrm{Ca}$ elevations is consistent with a primary role for $I_{\mathrm{CAN}}$ in mediating this response, as is the observation that we could mimic the ADP response by uncaging $\mathrm{Ca}$ in granule cells. Also consistent with this proposed mechanism was the ability of FFA, a relatively nonspecific agent that has been reported to antagonize $I_{\mathrm{CAN}}$-mediated responses (Partridge and Valenzuela, 2000; Ghamari-Langroudi and Bourque, 2002; Pressler and Strowbridge, 2006), to reduce the ADP in granule 
cells and the blockade of the Ca spike-evoked ADP response we observed after NMG substitution.

Whereas our findings indicate that muscarinic receptors function to enhance granule cell excitability, a previous report (Castillo et al., 1999) reached the opposite conclusion based on the ability of CCh and oxotremorine to depress the spontaneous firing rate in cell-attached granule cell recordings. One difference between these studies is the concentration of CCh used [our study used $2 \mu \mathrm{M}$ whereas the study by Castillo et al. (1999) used 50 $\mu \mathrm{M}$. However, we also consistently observed an increased excitability at this higher concentration of $\mathrm{CCh}$, as long as the test stimulus was not so strong that the cell went into depolarization block in CCh (Fig. 4). Another difference between the two studies was that the study by Castillo et al. (1999) examined spontaneous firing rates, whereas our study focused on both intracellular responses to depolarizing stimuli and firing changes in cellattached recordings. A third difference is that none of our granule cells recorded under whole-cell mode was spontaneously active in control conditions (mean RMP with no current injected, $-74.3 \pm 1.6 \mathrm{mV}$; range from -85 to $-63 \mathrm{mV}$ ) whereas this component of the study by Castillo et al. (1999) focused on cellattached recordings that exhibited spontaneous spiking. This discrepancy in basal activity may reflect multiple populations of neurons located in the granule cell layer, which may express different types of muscarinic receptors or effector mechanisms.

\section{Comparison with functional effects of HDB stimulation in vivo}

The functional effects of activating cholinergic HDB neurons on mitral and granule cells in the olfactory bulb were the focus of three previous studies (Inokuchi et al., 1987; Nickell and Shipley, 1988; Kunze et al., 1992). Two of these studies (Inokuchi et al., 1987; Nickell and Shipley, 1988) found results suggesting the primary effect was excitation of interneurons located in the granule cell layer: negative-going field potentials in the granule cell layer in the former study and potentiation of inhibition onto mitral cells by repetitive HDB stimulation in the latter study. Both findings are generally consistent with the AHP-to-ADP function we describe here and with the tonic depolarization produced by CCh discussed above. The study by Kunze et al. (1992) found the opposite result: slowly rising hyperpolarizations after HDB stimulation in granule cells visualized with Lucifer yellow. Although at odds with our results, the presence of HDB-driven hyperpolarizations in granule cells is consistent with the findings of Castillo et al. (1999), which found that activating muscarinic receptors slowed spontaneous firing in presumptive granule cells.

Although the basis for the discrepancy between these studies remains unclear, there are at least three possible explanations. First, the HDB is heterogenous and includes GABAergic neurons (Brashear et al., 1986) that project to the olfactory bulb ( $\mathrm{Za}-$ borszky et al., 1986). It is possible that the postsynaptic hyperpolarization reported by Kunze et al. (1992) reflects activation of these projecting GABAergic HDB neurons. Alternatively, HDB stimulation may activate other types of GABAergic interneurons located in the granule cell layer, such as Blanes cells (Pressler and Strowbridge, 2006), that inhibit granule cells. Finally, these differences may reflect subpopulations of granule cells that respond differently to cholinergic inputs.

\section{Possible role of postsynaptic cholinergic receptors in the olfactory bulb}

Although the complexity of the cholinergic system and its known effecter mechanisms likely precludes any simple hypothesis to explain the role of ACh in the olfactory bulb, our results suggest three potential roles for postsynaptic $M_{1}$ receptors on granule cells. At the most direct level, this mechanism increases granule cell excitability, and presumably GABAergic inhibition onto synaptically coupled mitral and tufted cells. Although CCh also may modulate GABA release from granule cells (Castillo et al., 1999; Ghatpande et al., 2006), the close similarity between the effects of $\mathrm{CCh}$ in cell-attached granule cell recordings (Fig. $6 B_{1}$ ) and the pattern of evoked inhibition onto mitral cells (Fig. $6 B_{2}$ ) suggest that an increase in interneuronal excitability is sufficient to explain our results. The selective enhancement of late responses to stimulus trains (Fig. 6C) also is consistent with a time-dependent modulation in intrinsic physiology.

The increase in granule cell excitability we find in CCh is consistent with the "sharpening" role often attributed to cholinergic inputs to the bulb (Linster and Hasselmo, 1997; Linster and Cleland, 2002; Mandairon et al., 2006). Increased self and lateral inhibition would be expected to decrease activity in off-beam mitral cells not strongly stimulated by sensory neuron axons. Presumably one consequence of increased lateral inhibition is to force the output of the olfactory bulb to more closely resemble the spatiotemporal pattern of its glomerular inputs. Although appealing for its intuitive parallels with the visual system, this hypothesis has yet to be tested thoroughly in the bulb and may be in conflict with other known functions of granule cell-mediated inhibition, such as generation of high-frequency network oscillations and rebound spikes in mitral cells (Desmaisons et al., 1999; Friedman and Strowbridge, 2003; Balu and Strowbridge, 2007).

The other relatively straightforward cellular effect of $M_{1}$ receptor stimulation is to enable granule cells to respond more robustly to repetitive stimuli. Under normal conditions in both slices (in the present study) and in vivo (Cang and Isaacson, 2003), responses to phasic sniffing-like stimuli are quickly dampened, presumably, at least in part, because of the intrinsic afterhyperpolarization response. Unfortunately, no data are available yet to determine whether adaptation of inspiration-driven granule cell responses is modulated by $\mathrm{M}_{1}$ receptors in vivo. Several lines of evidence suggest that performance on complex olfactory discrimination tasks is enhanced when rodents are able to use information from multiple sniffs (Rinberg et al., 2006). Activation of $\mathrm{M}_{1}$ receptors on granule cells may contribute to the effective integration of sensory information driven by these late sniffs. In addition to these effects on adaptation during repetitive stimuli, our results suggest that muscarinic receptor activation accelerates granule cell firing and, therefore, the phase relationship of inhibition onto mitral cells.

Finally, most intriguing but also most speculative is the possibility that the quasipersistent firing mode we report in granule cells after cholinergic stimulation may contribute to short-term olfactory memory. This finding is consistent with behavioral studies linking the cholinergic system to olfactory working memory, including the direct demonstration by Ravel et al. (1994) that focal injection of scopolamine into the granule cell layer disrupts short-term olfactory memory. However, one potential problem with this hypothesis is the relatively large difference between granule cell resting potential and the threshold for evoking persistent firing. Unlike Blanes cells, which rest very close to their firing threshold (Pressler and Strowbridge, 2006), granule cells normally rest at more hyperpolarized potentials. This difference is not as large when granule cells are recorded in vivo (Cang and Isaacson, 2003), raising the possibility that coordinated modulation (perhaps triggered by attention- or motivation-related neural signals) might bring granule cell membrane potentials into the 
range where intrinsic $I_{\mathrm{CAN}}$ currents can trigger autonomous firing. Although it seems likely that $I_{\mathrm{CAN}^{-}}$-mediated responses can prolong granule cell discharges during individual inspiration cycles, additional experiments will be necessary to determine whether $\mathrm{M}_{1}$-related mechanisms enable granule cells to maintain their firing autonomously for many seconds in vivo.

\section{References}

Albers MW, Tabert MH, Devanand DP (2006) Olfactory dysfunction as a predictor of neurodegenerative disease. Curr Neurol Neurosci Rep 6:379-386

Balu R, Strowbridge BW (2007) Opposing inward and outward conductances regulate rebound spiking in olfactory bulb mitral cells. J Neurophysiol 97:1959-1968.

Balu R, Larimer P, Strowbridge BW (2004) Phasic stimuli evoke precisely timed spikes in intermittently discharging mitral cells. J Neurophysiol 92:743-753.

Brashear HR, Zaborszky L, Heimer L (1986) Distribution of GABAergic and cholinergic neurons in the rat diagonal band. Neuroscience 17:439-451.

Buckley NJ, Bonner TI, Brann MR (1988) Localization of a family of muscarinic receptor mRNAs in rat brain. J Neurosci 8:4646-4652.

Cang J, Isaacson JS (2003) In vivo whole-cell recording of odor-evoked synaptic transmission in the rat olfactory bulb. J Neurosci 23:4108-4116.

Castillo PE, Carleton A, Vincent JD, Lledo PM (1999) Multiple and opposing roles of cholinergic transmission in the main olfactory bulb. J Neurosci 19:9180-9191.

Charpak S, Mertz J, Beaurepaire E, Moreaux L, Delaney K (2001) Odorevoked calcium signals in dendrites of rat mitral cells. Proc Natl Acad Sci USA 98:1230-1234.

Chen WR, Shepherd GM (1997) Membrane and synaptic properties of mitral cells in slices of rat olfactory bulb. Brain Res 745:189-196.

Cole AE, Nicoll RA (1983) Acetylcholine mediates a slow synaptic potential in hippocampal pyramidal cells. Science 221:1299-1301.

Crespo C, Blasco-Ibanez JM, Brinon JG, Alonso JR, Dominguez MI, Martinez-Guijarro FJ (2000) Subcellular localization of $\mathrm{m} 2$ muscarinic receptors in GABAergic interneurons of the olfactory bulb. Eur J Neurosci 12:3963-3974.

Desmaisons D, Vincent JD, Lledo PM (1999) Control of action potential timing by intrinsic subthreshold oscillations in olfactory bulb output neurons. J Neurosci 19:10727-10737.

Doty RL, Bagla R, Kim N (1999) Physostigmine enhances performance on an odor mixture discrimination test. Physiol Behav 65:801-804.

Durand M, Coronas V, Jourdan F, Quirion R (1998) Developmental and aging aspects of the cholinergic innervation of the olfactory bulb. Int J Dev Neurosci 16:777-785.

Egorov AV, Hamam BN, Fransen E, Hasselmo ME, Alonso AA (2002) Graded persistent activity in entorhinal cortex neurons. Nature 420:173-178.

Ellis-Davies GC, Kaplan JH (1994) Nitrophenyl-EGTA, a photolabile chelator that selectively binds $\mathrm{Ca}^{2+}$ with high affinity and releases it rapidly upon photolysis. Proc Natl Acad Sci USA 91:187-191.

Ferreyra-Moyano H, Barragan E (1989) The olfactory system and Alzheimer's disease. Int J Neurosci 49:157-197.

Fletcher ML, Wilson DA (2002) Experience modifies olfactory acuity: acetylcholine-dependent learning decreases behavioral generalization between similar odorants. J Neurosci 22:RC201.

Fraser DD, MacVicar BA (1996) Cholinergic-depedent plateau potential in hippocampal CA1 pyramidal neurons. J Neurosci 16:4113-4128.

Friedman D, Strowbridge BW (2003) Both electrical and chemical synapses mediate fast network oscillations in the olfactory bulb. J Neurophysiol 89:2601-2610.

Ghamari-Langroudi M, Bourque CW (2002) Flufenamic acid blocks depolarizing afterpotentials and phasic firing in rat supraoptic neurones. J Physiol (Lond) 545:537-542.

Ghatpande AS, Sivaraaman K, Vijayaraghavan S (2006) Store calcium mediates cholinergic effects on mIPSCs in the rat main olfactory bulb. J Neurophysiol 95:1345-1355.

Haj-Dahmane S, Andrade R (1998) Ionic mechanism of the slow afterdepolarization induced by muscarinic receptor activation in rat prefrontal cortex. J Neurophysiol 80:1197-1210.

Haj-Dahmane S, Andrade R (1999) Muscarinic receptors regulate two dif- ferent calcium-dependent non-selective cation currents in rat prefrontal cortex. Eur J Neurosci 11:1973-1980.

Halabisky B, Strowbridge BW (2003) Gamma-frequency excitatory input to granule cells facilitates dendrodendritic inhibition in the rat olfactory Bulb. J Neurophysiol 90:644-654.

Halabisky B, Friedman D, Radojicic M, Strowbridge BW (2000) Calcium influx through NMDA receptors directly evokes GABA release in olfactory bulb granule cells. J Neurosci 20:5124-5134.

Halasz N, Greer CA (1993) Terminal arborizations of olfactory nerve fibers in the glomeruli of the olfactory bulb. J Comp Neurol 337:307-316.

Hall BJ, Delaney KR (2002) Contribution of a calcium-activated nonspecific conductance to NMDA receptor-mediated synaptic potentials in granule cells of the frog olfactory bulb. J Physiol (Lond) 543:819-834.

Hammer R, Berrie CP, Birdsall NJ, Burgen AS, Hulme EC (1980) Pirenzepine distinguishes between different subclasses of muscarinic receptors. Nature 283:90-92.

Hammer R, Giraldo E, Schiavi GB, Monferini E, Ladinsky H (1986) Binding profile of a novel cardioselective muscarine receptor antagonist, AF-DX 116 , to membranes of peripheral tissues and brain in the rat. Life Sci 38:1653-1662.

Inokuchi A, Restrepo JP, Snow Jr JB (1987) Effect of stimulation of the horizontal limb of the diagonal band on rat olfactory bulb neuronal activity. Am J Otolaryngol 8:205-210.

Isaacson JS, Strowbridge BW (1998) Olfactory reciprocal synapses: dendritic signaling in the CNS. Neuron 20:749-761.

Jahr CE, Nicoll RA (1980) Dendrodendritic inhibition: demonstration with intracellular recording. Science 207:1473-1475.

Kasa P, Hlavati I, Dobo E, Wolff A, Joo F, Wolff JR (1995) Synaptic and non-synaptic cholinergic innervation of the various types of neurons in the main olfactory bulb of adult rat: immunocytochemistry of choline acetyltransferase. Neuroscience 67:667-677.

Kunze WA, Shafton AD, Kemm RE, McKenzie JS (1991) Effect of stimulating the nucleus of the horizontal limb of the diagonal band on single unit activity in the olfactory bulb. Neuroscience 40:21-27.

Kunze WA, Shafton AD, Kem RE, McKenzie JS (1992) Intracellular responses of olfactory bulb granule cells to stimulating the horizontal diagonal band nucleus. Neuroscience 48:363-369.

Lawrence JJ, Grinspan ZM, Statland JM, McBain CJ (2006) Muscarinic receptor activation tunes mouse stratum oriens interneurons to amplify spike reliability. J Physiol (Lond) 571:555-562.

Le Jeune H, Aubert I, Jourdan F, Quirion R (1995) Comparative laminar distribution of various autoradiographic cholinergic markers in adult rat main olfactory bulb. J Chem Neuroanat 9:99-112.

Le Jeune H, Aubert I, Jourdan F, Quirion R (1996) Developmental profiles of various cholinergic markers in the rat main olfactory bulb using quantitative autoradiography. J Comp Neurol 373:433-450.

Linster C, Cleland TA (2002) Cholinergic modulation of sensory representations in the olfactory bulb. Neural Netw 15:709-717.

Linster C, Hasselmo M (1997) Modulation of inhibition in a model of olfactory bulb reduces overlap in the neural representation of olfactory stimuli. Behav Brain Res 84:117-127.

Linster C, Garcia PA, Hasselmo ME, Baxter MG (2001a) Selective loss of cholinergic neurons projecting to the olfactory system increases perceptual generalization between similar, but not dissimilar, odorants. Behav Neurosci 115:826-833.

Linster C, Johnson BA, Yue E, Morse A, Xu Z, Hingco EE, Choi Y, Choi M, Messiha A, Leon M (2001b) Perceptual correlates of neural representations evoked by odorant enantiomers. J Neurosci 21:9837-9843.

Luskin MB, Price JL (1982) The distribution of axon collaterals from the olfactory bulb and the nucleus of the horizontal limb of the diagonal band to the olfactory cortex, demonstrated by double retrograde labeling techniques. J Comp Neurol 209:249-263.

Luskin MB, Price JL (1983) The topographic organization of associational fibers of the olfactory system in the rat, including centrifugal fibers to the olfactory bulb. J Comp Neurol 216:264-291.

Macrides F, Chorover SL (1972) Olfactory bulb units: activity correlated with inhalation cycles and odor quality. Science 175:84-87.

Macrides F, Davis BJ, Youngs WM, Nadi NS, Margolis FL (1981) Cholinergic and catecholaminergic afferents to the olfactory bulb in the hamster: a neuroanatomical, biochemical, and histochemical investigation. J Comp Neurol 203:495-514.

Mandairon N, Ferretti CJ, Stack CM, Rubin DB, Cleland TA, Linster C (2006) 
Cholinergic modulation in the olfactory bulb influences spontaneous olfactory discrimination in adult rats. Eur J Neurosci 24:3234-3244.

Margrie TW, Schaefer AT (2003) Theta oscillation coupled spike latencies yield computational vigour in a mammalian sensory system. J Physiol (Lond) 546:363-374.

McQuiston AR, Madison DV (1999) Muscarinic receptor activity induces an afterdepolarization in a subpopulation of hippocampal CA1 interneurons. J Neurosci 19:5703-5710.

Nickell WT, Shipley MT (1988) Neurophysiology of magnocellular forebrain inputs to the olfactory bulb in the rat: frequency potentiation of field potentials and inhibition of output neurons. J Neurosci 8:4492-4502.

Partridge LD, Valenzuela CF (2000) Block of hippocampal CAN channels by flufenamate. Brain Res 867:143-148.

Patton C, Thompson S, Epel D (2004) Some precautions in using chelators to buffer metals in biological solutions. Cell Calcium 35:427-431.

Pressler RT, Strowbridge BW (2006) Blanes cells mediate persistent feedforward inhibition onto granule cells in the olfactory bulb. Neuron 49:889-904.

Rall W, Shepherd GM, Reese TS, Brightman MW (1966) Dendrodendritic synaptic pathway for inhibition in the olfactory bulb. Exp Neurol 14:44-56.

Ravel N, Vigouroux M, Elaagouby A, Gervais R (1992) Scopolamine impairs delayed matching in an olfactory task in rats. Psychopharmacology (Berl) 109:439-443.

Ravel N, Elaagouby A, Gervais R (1994) Scopolamine injection into the olfactory bulb impairs short-term olfactory memory in rats. Behav Neurosci 108:317-324.

Rinberg D, Koulakov A, Gelperin A (2006) Speed-accuracy tradeoff in olfaction. Neuron 51:351-358.

Roman FS, Simonetto I, Soumireu-Mourat B (1993) Learning and memory of odor-reward association: selective impairment following horizontal diagonal band lesions. Behav Neurosci 107:72-81.

Shepherd GM, Greer CA (1998) Olfactory bulb. In: Synaptic organization of the brain, Ed 4 (Shepherd GM, ed), pp 159-204. New York: Oxford UP.

Wilson DA, Fletcher ML, Sullivan RM (2004) Acetylcholine and olfactory perceptual learning. Learn Mem 11:28-34.

Zaborszky L, Carlsen J, Brashear HR, Heimer L (1986) Cholinergic and GABAergic afferents to the olfactory bulb in the rat with special emphasis on the projection neurons in the nucleus of the horizontal limb of the diagonal band. J Comp Neurol 243:488-509. 